\title{
Foto-imagens de acasos
}

\section{Arlete Brito e Antonio Miguel}


Terapeuticamente movidos pelo acaso do lockdown pandêmico e munidos de softwares computacionais, de fotografias produzidas por eles mesmos e de outras foto-imagens disponiveis no ciberespaço que tematizam acasos em diferentes campos de atividade fumana produzimos, mediante o recurso de transfiguração artísticocriativa dessas foto-imagens e orientados pelo aforismo de Albert Einstein de que "Deus não joga dados", outras foto-imagens de acasos. 
o resultado desta nossa ciberviagem sem lenço e sem documento é aqui apresentado sob a forma de um álbum virtual de foto-imagens de acasos, ao qual leitores e leitoras, dando asas à imaginação e à criatividade, poderão acrescentar novas págínas, produzindo suas próprias fotoimagens de acasos. Este álbum foi disponibilizado nas plataformas Issuu e Flickr na primeira exposição vírtual promovida pelo Centro Cultural Martha Watts da Universidade Metodista (UNTMEP) de Piraciba-SP, a partir de 15 de outubro de 2020, nos links: (https://issuu.com/ ccmarthawatts/docs/fotoimagens_de_acasos)e

(https://www.flickr.com/photos/ 126466208@No6/atbums/ $72157716093450002)$. 
Até o día 31 de dezembro de 2020, o álbum contava com 345 vísualizações. Fle contém 33 fotoimagens. Um clicar sobre qualquer uma delas levará leitores e leitoras a uma nota contendo referências e esclarecimentos relativos ao modo de produção da foto-imagem correspondente. Um clicar sobre a nota os farão retornar à fotoimagem correspondente do álbum. As foto-imagens de acasos produzidas podem ser vistas como jogos casuaís de linguagem que se abrem a significaçôes múltiplas, diversas e surpreendentes para os que se permitirem vê-las segundo o mote terapêutico - nem racional, nem irracional - que orienta 0 modo de Wittgenstein filosofar:

\section{NÃ̃O PENSE, VEJA !}




\section{O deus-arquiteto de Blake foga dados}

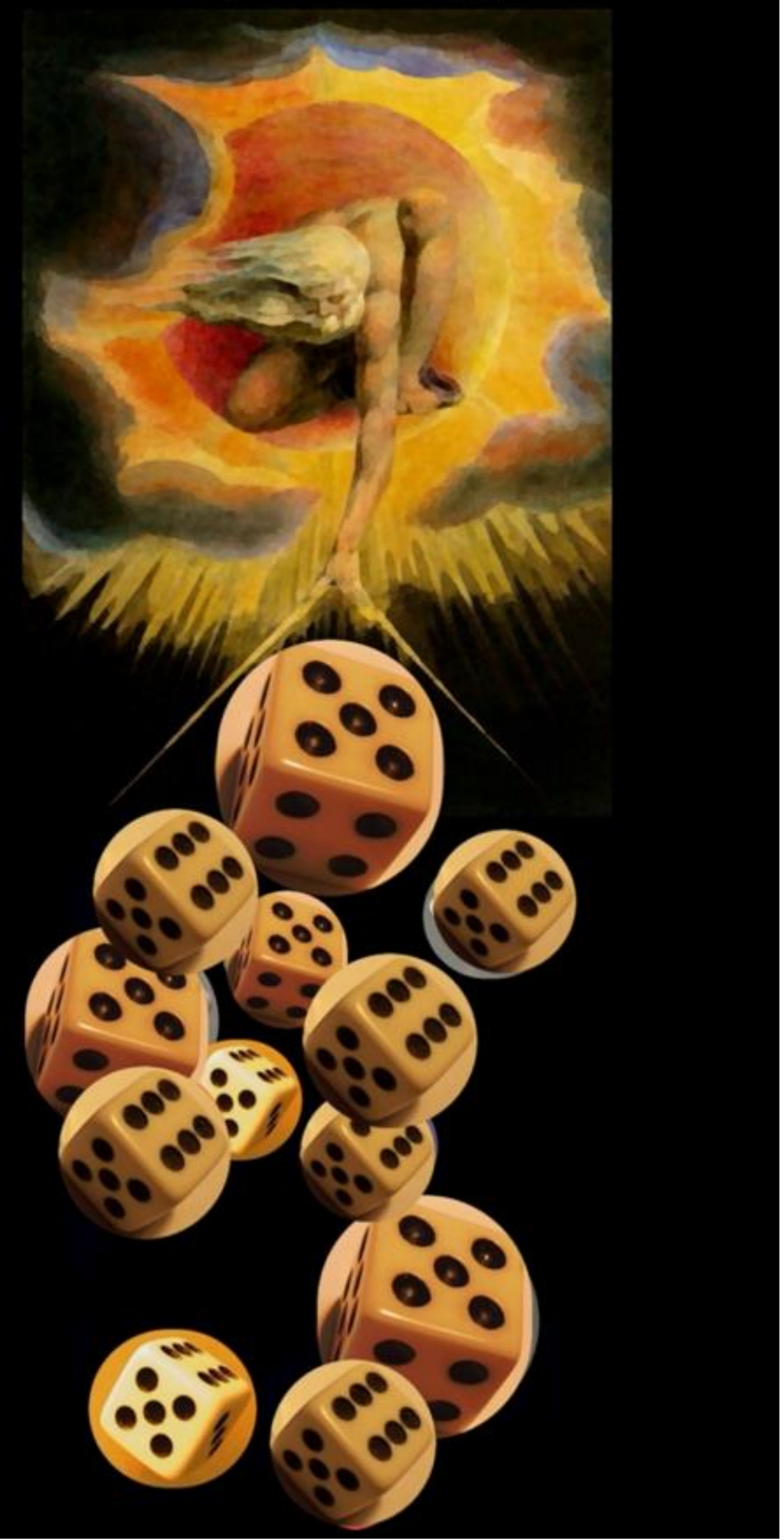




\section{O deus-arquiteto de Blake estima as probabilidades}

nos lances de antigos dados romanos

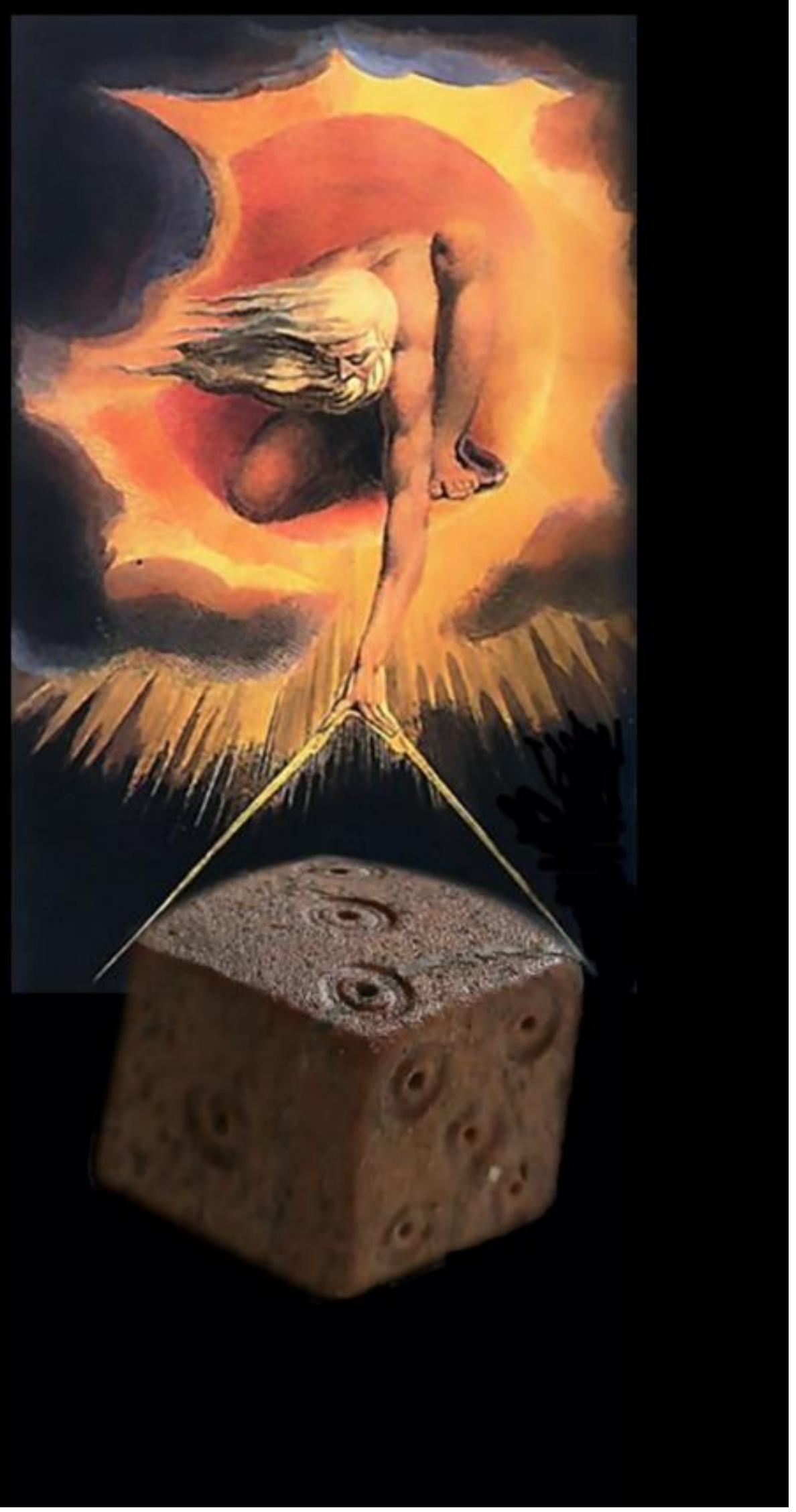




\section{O deus-arquiteto de Blake também joga dados de só 2 faces}

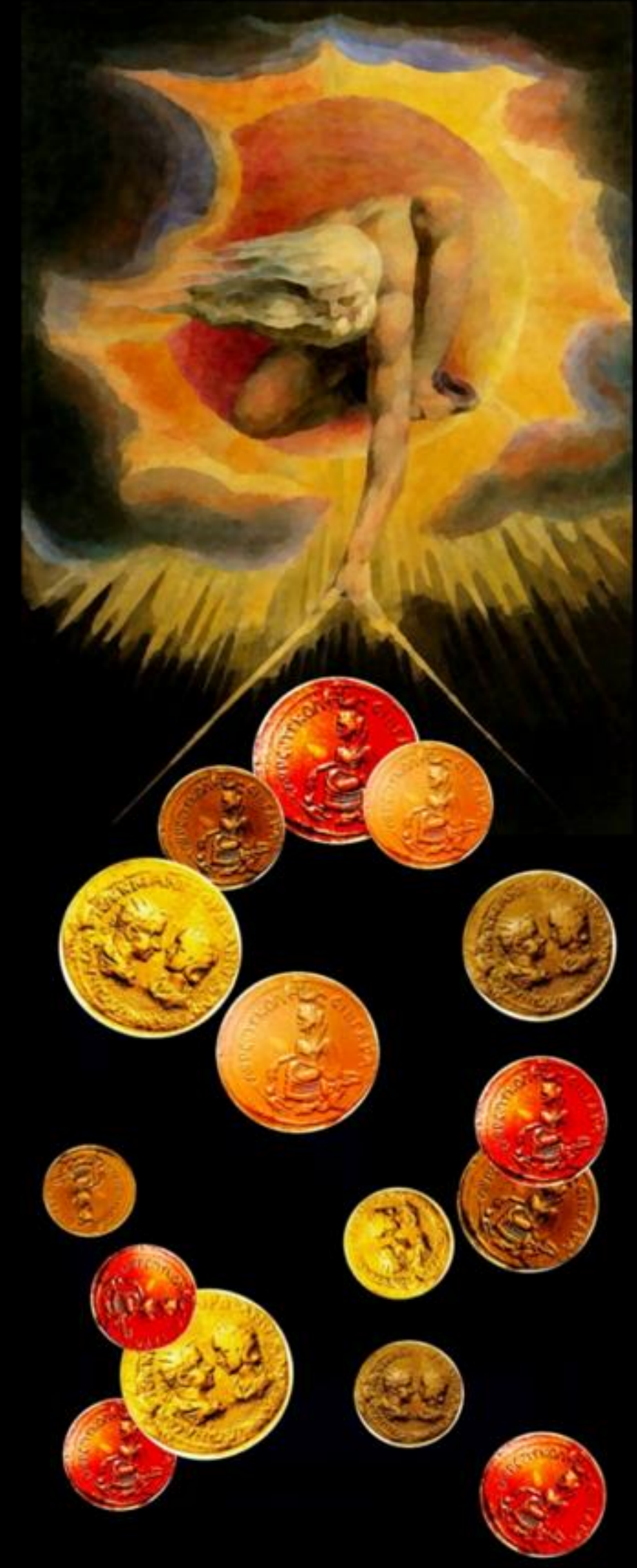


4. Já os supostos representantes de deuses na Terra não jogam com dados de 2 faces, mas com moedas

The Fara entender ena situaclo - e o pupel dar liderancas religionas no llanil.

Intercept

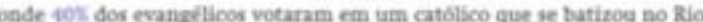

jonda e usa kiga -, coeversei em Nova York coen a decana da principal teniveraidade de Teologia dos Fth. No entendimento da reverenda Kerlly

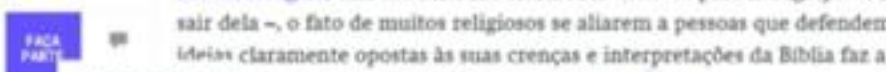

igreja setornar uma "instituicto nocial que por por acaso é religiosa
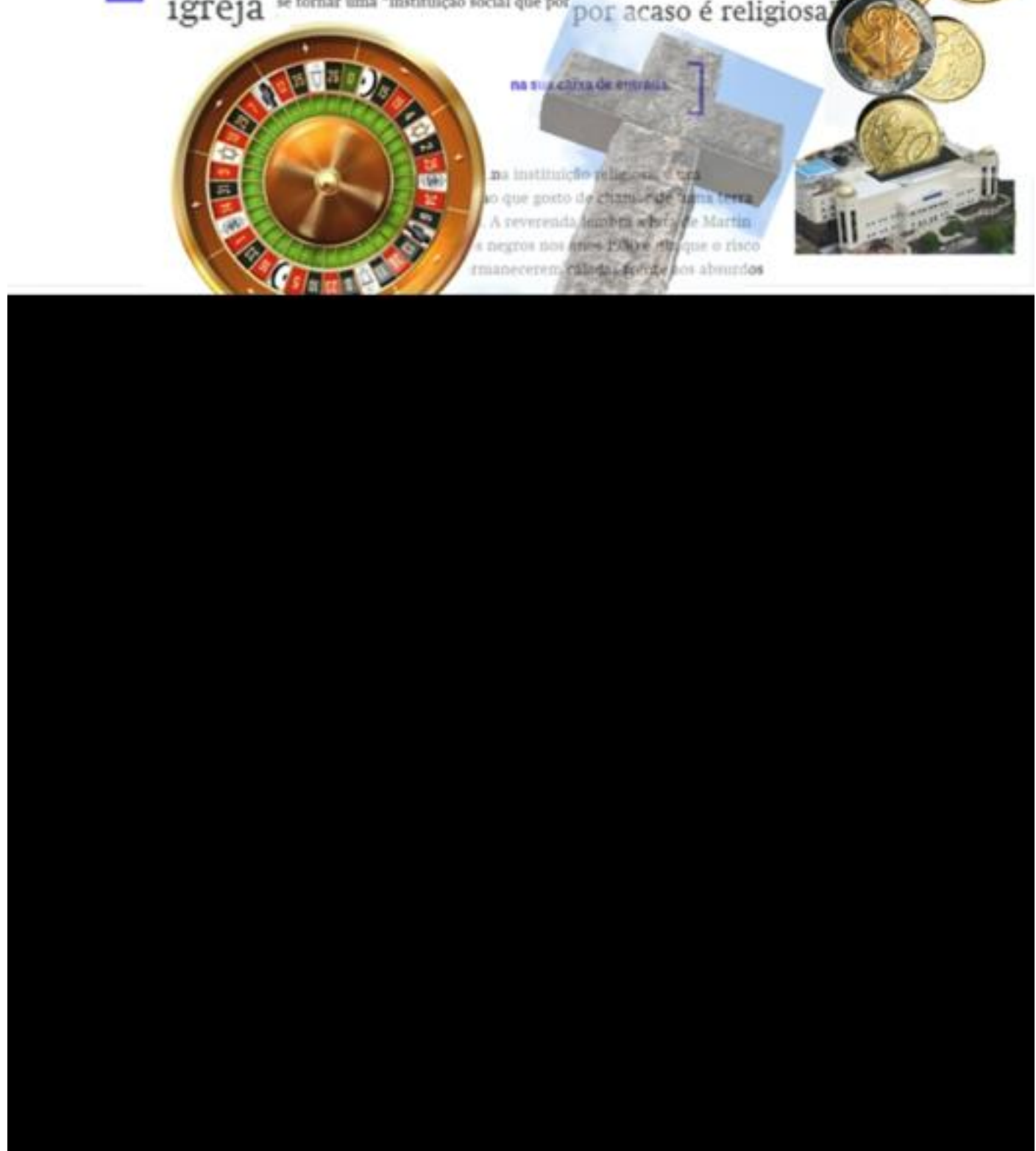
5. O deus-arquiteto de Blake, jogando com dados de só 2 faces de Tique, renova o Olimpo com outros deuses e deusas

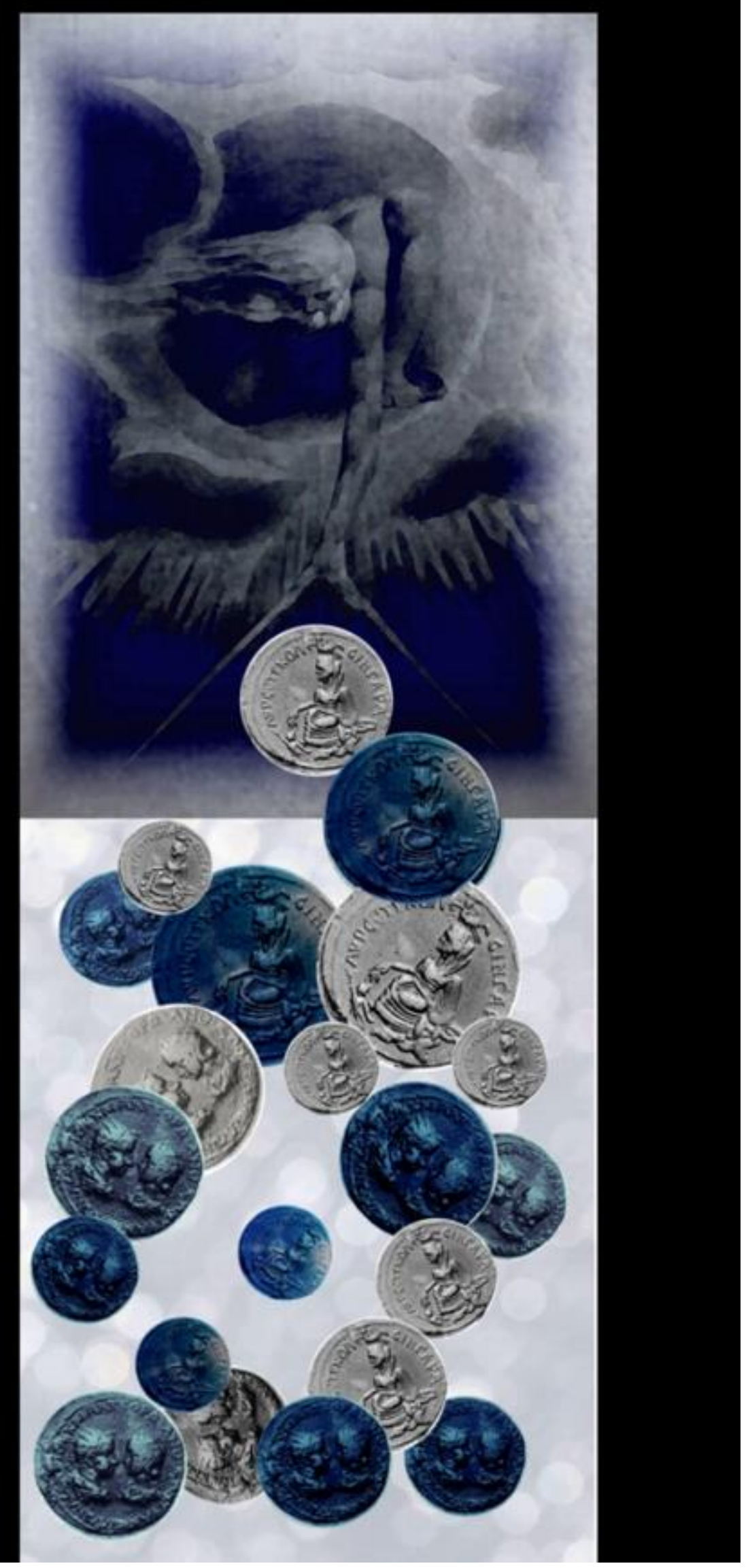




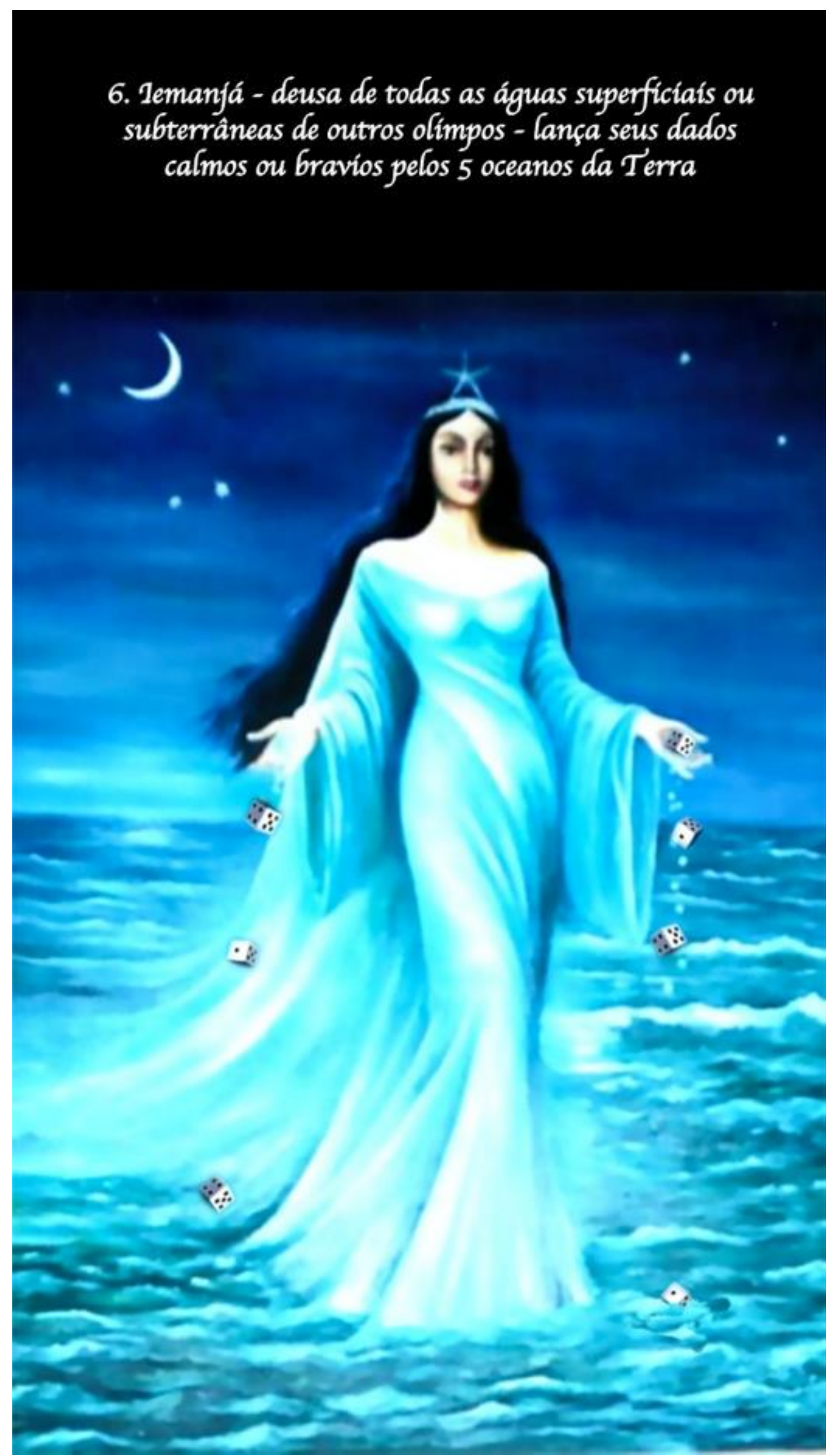




\section{Mas não antes de recuperar o seu rosto original}

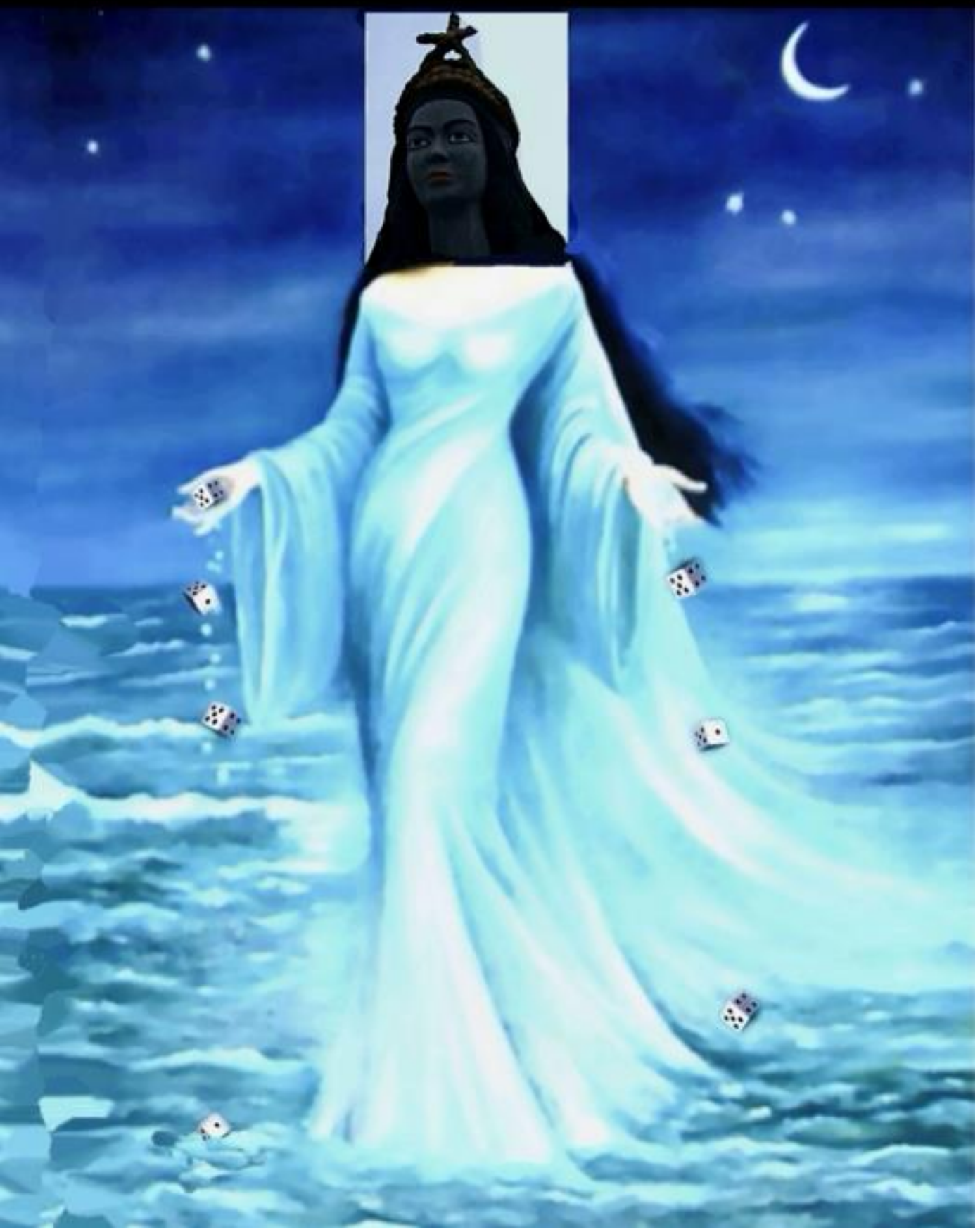


8. Estátuas humanas de deuses podem também lançar dados sobre túmulos de humanos

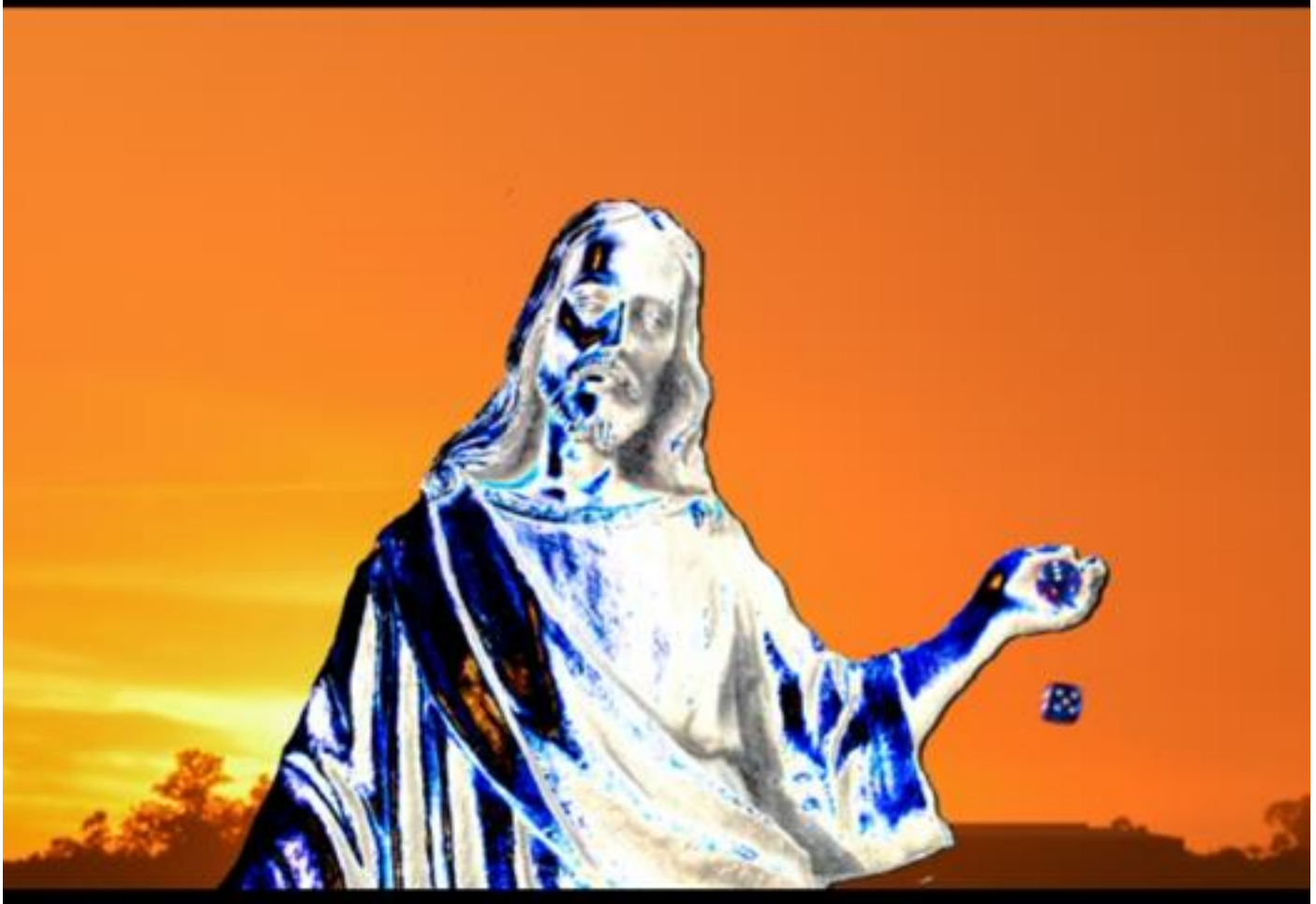


9. Sentada em uma flor de lótus, Lakshimí - deusa da fortuna de outros olimpos - brinca com místicos dados azul-Yves Xlein

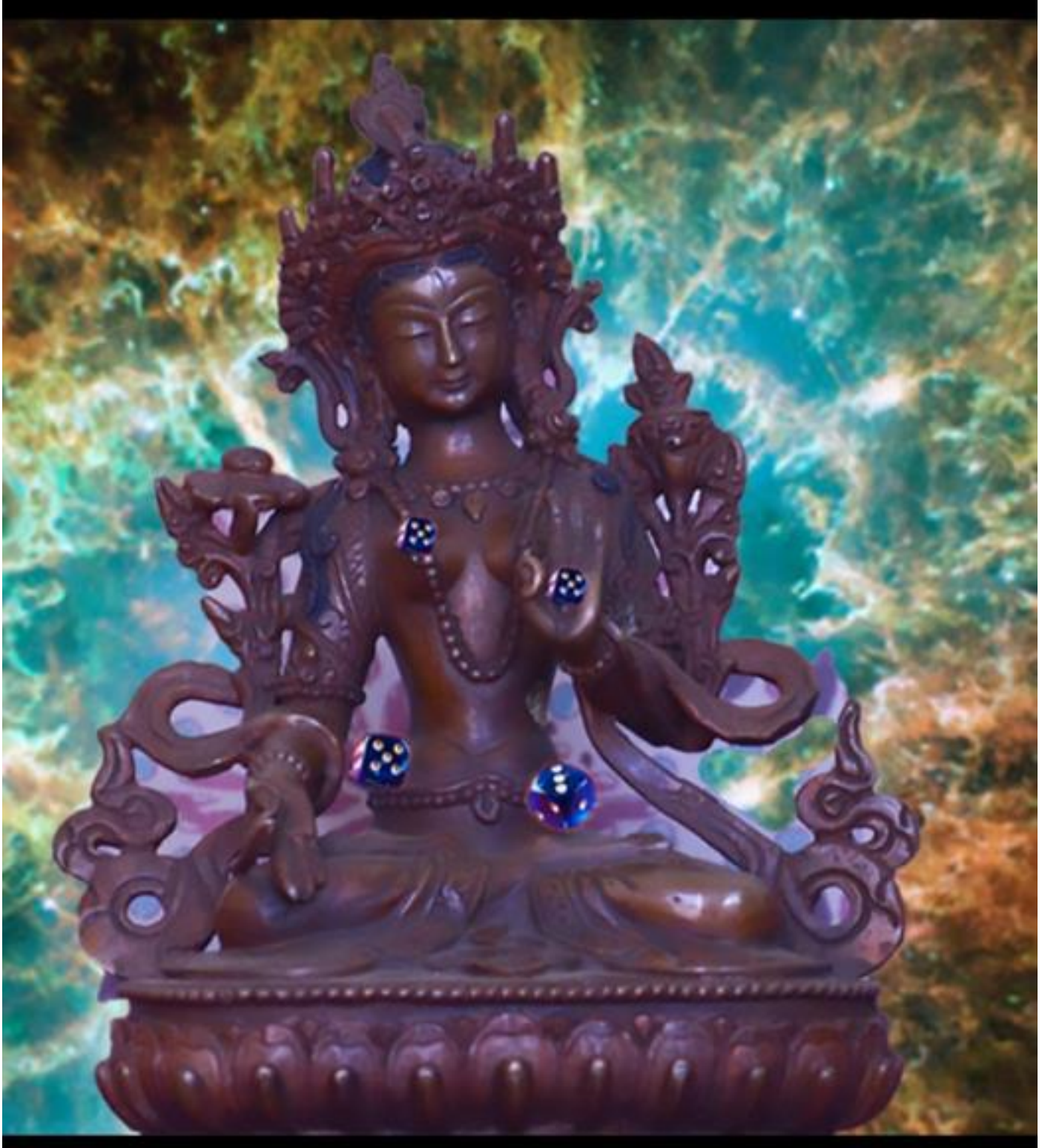


10. $\mathcal{E}$ este Buda medita lançando dados ancestraís

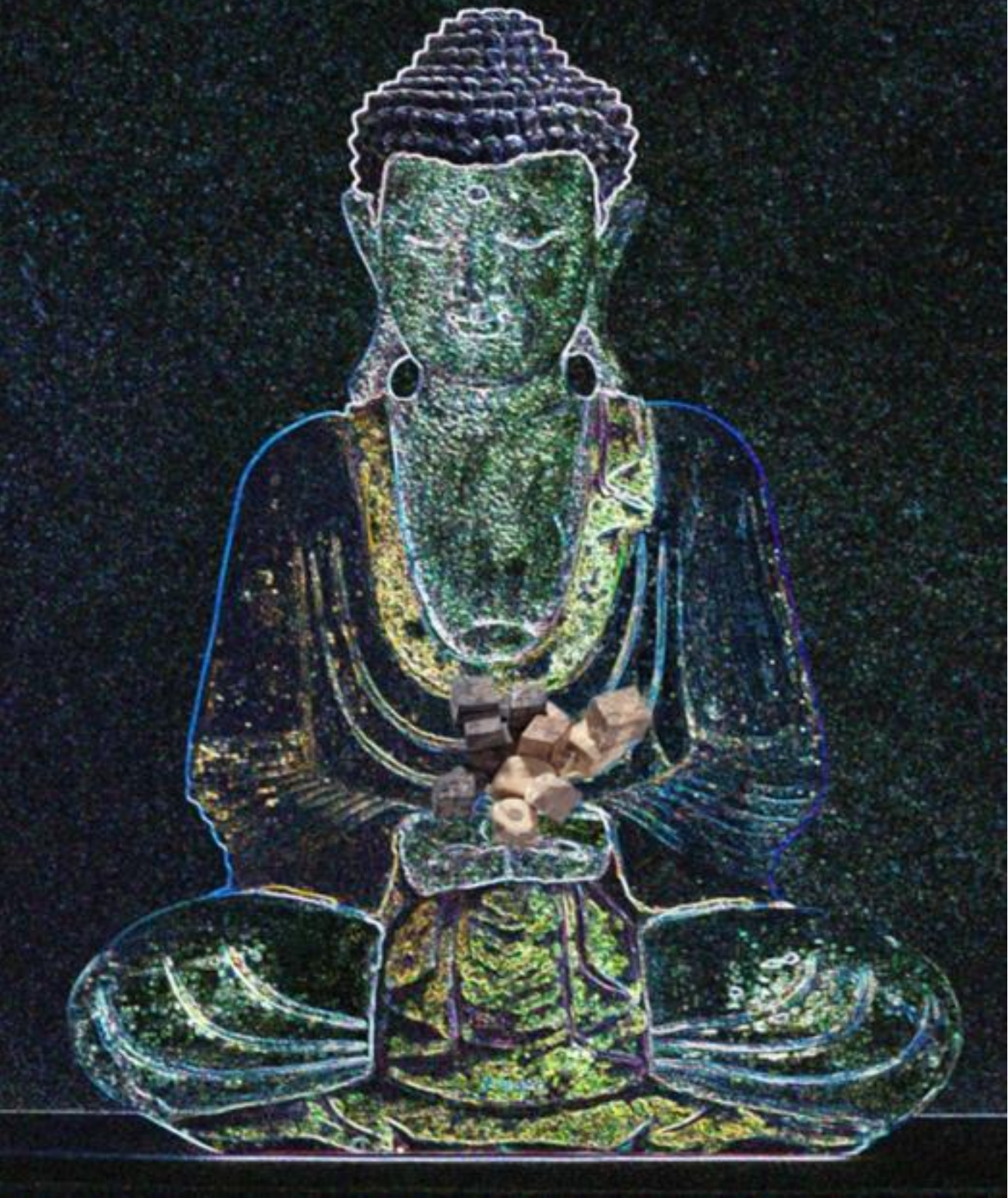


11. Na pesagem do coração de um réu, Anúbis, deus-juíz dos mortos de outros olimpos, usa um dado como fiet da Galança de Maat

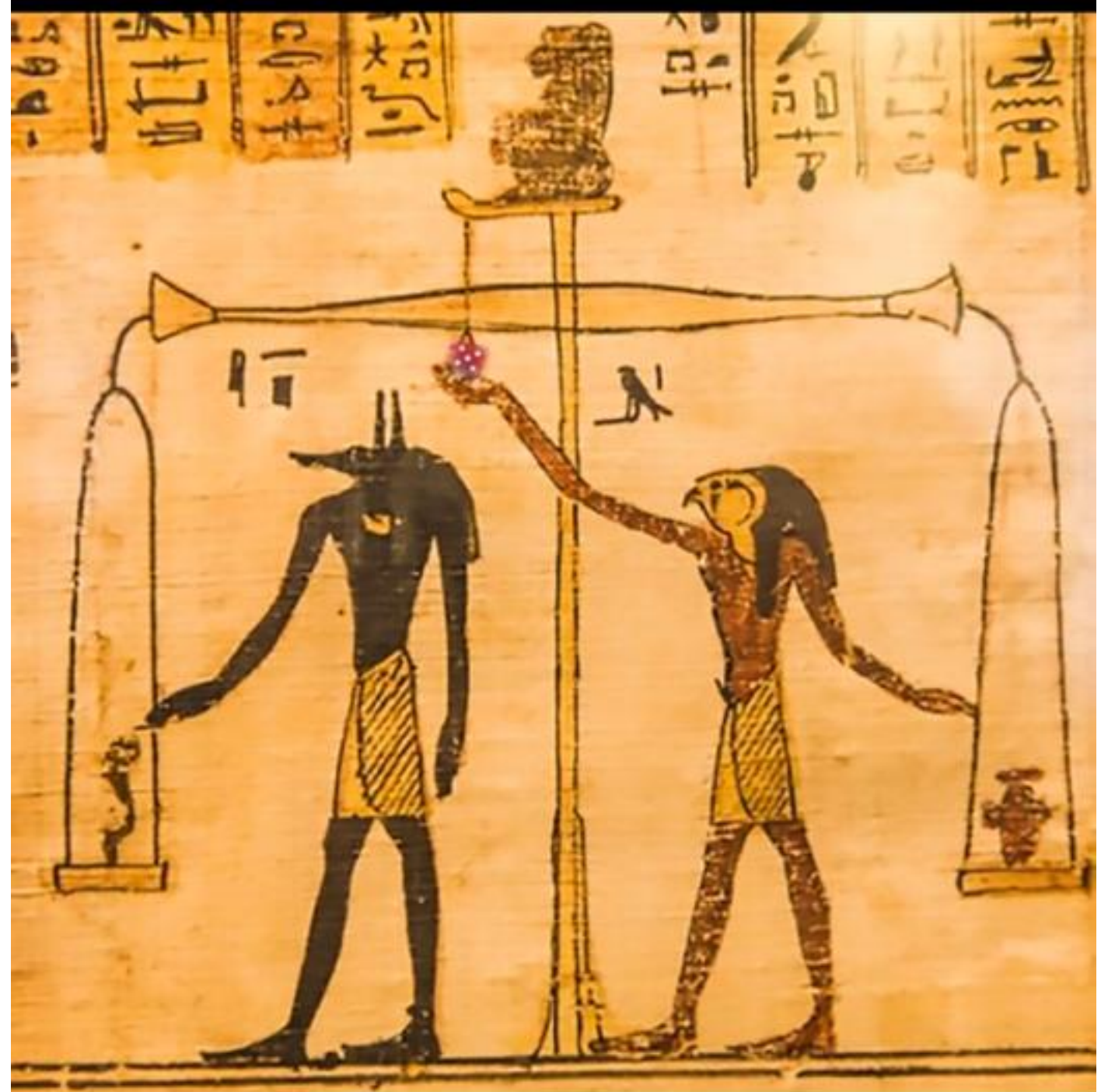


12. Enquanto o deus-arquiteto de Blake lança dados pandêmícos de infinitas faces vírulentas

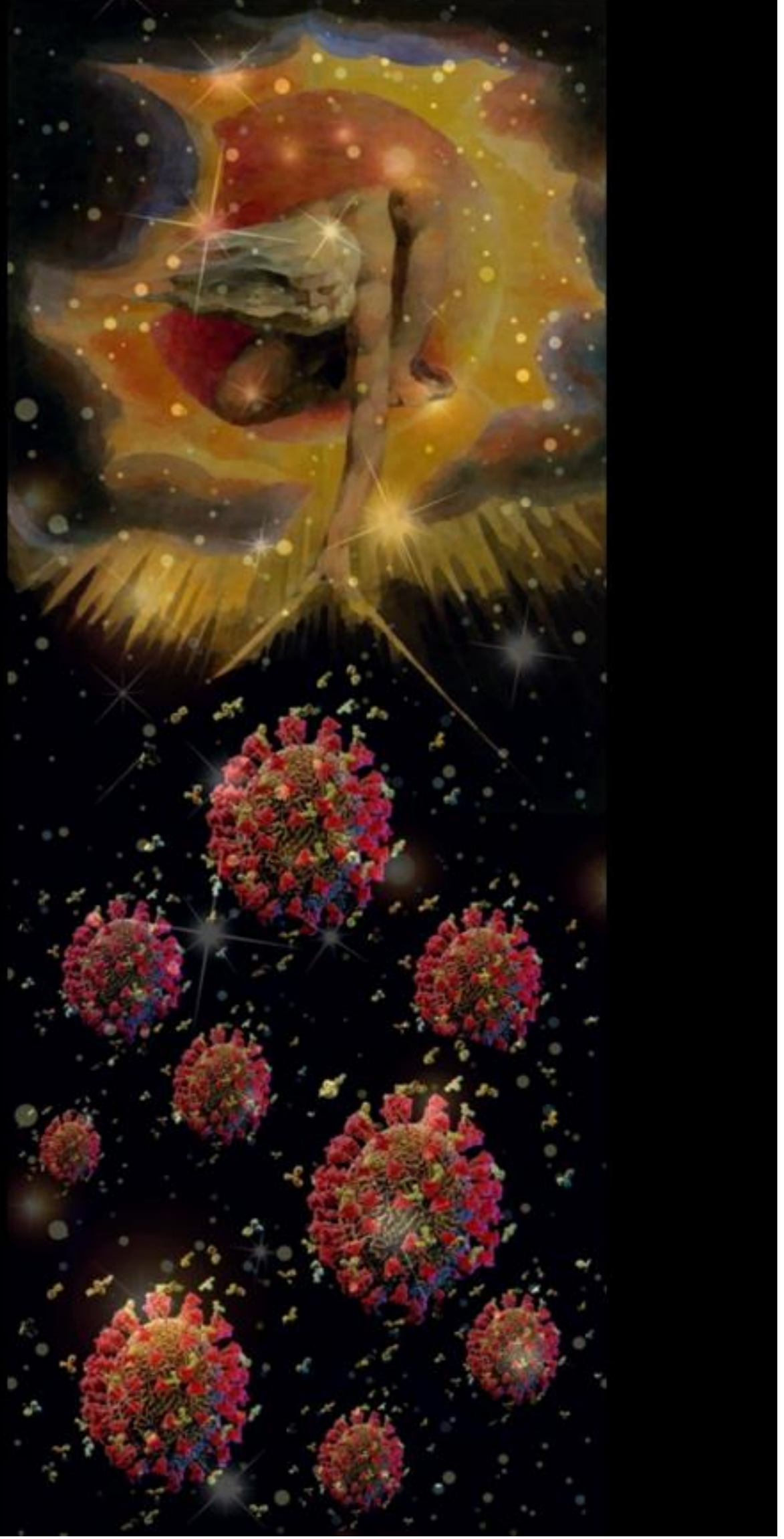




\section{Uma deusa medieval gíra a roda das fortunas}

ou dos infortúnios

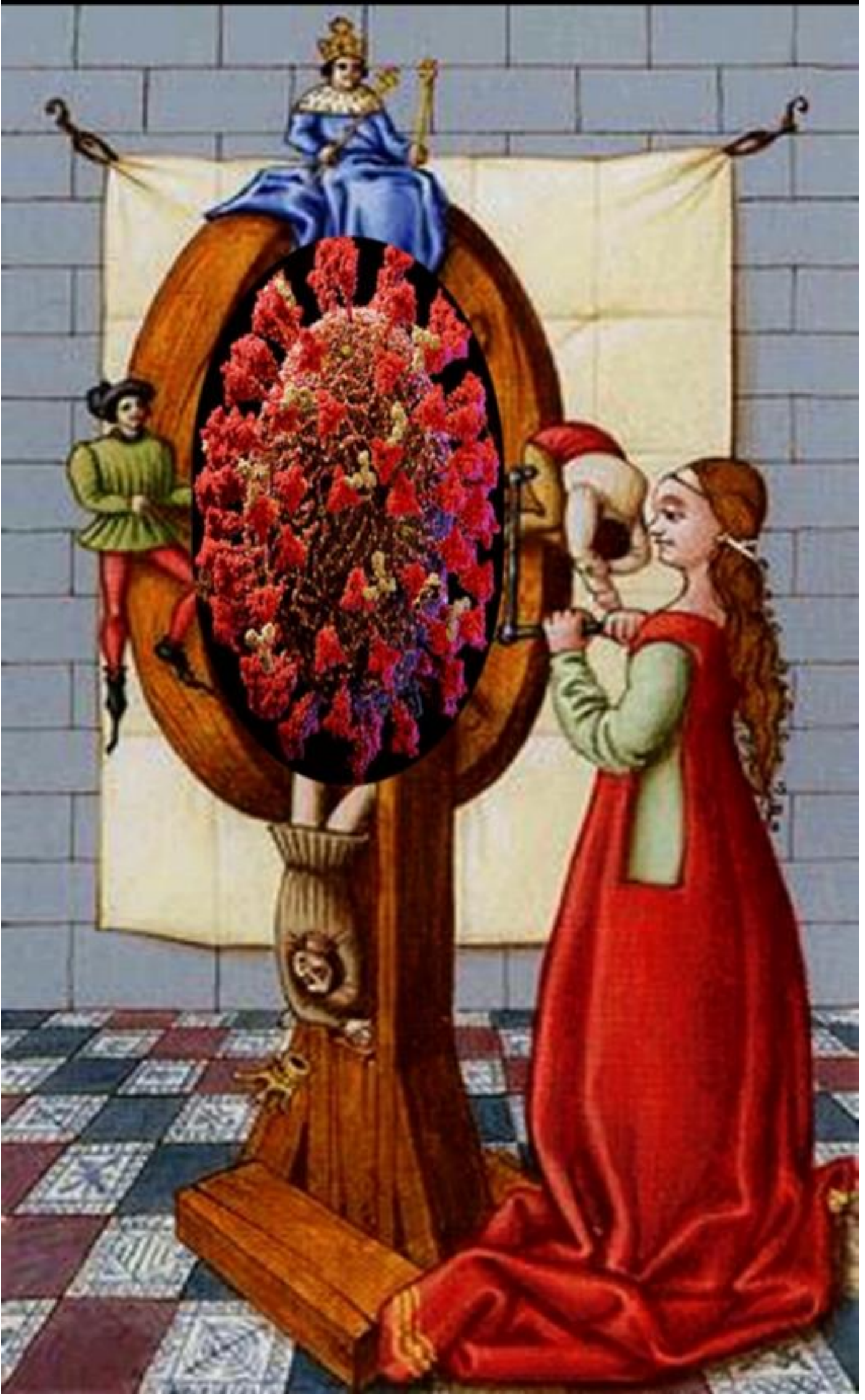


14. A rigor, deuses não jogam dados. São os cientístas que o fazem por eles

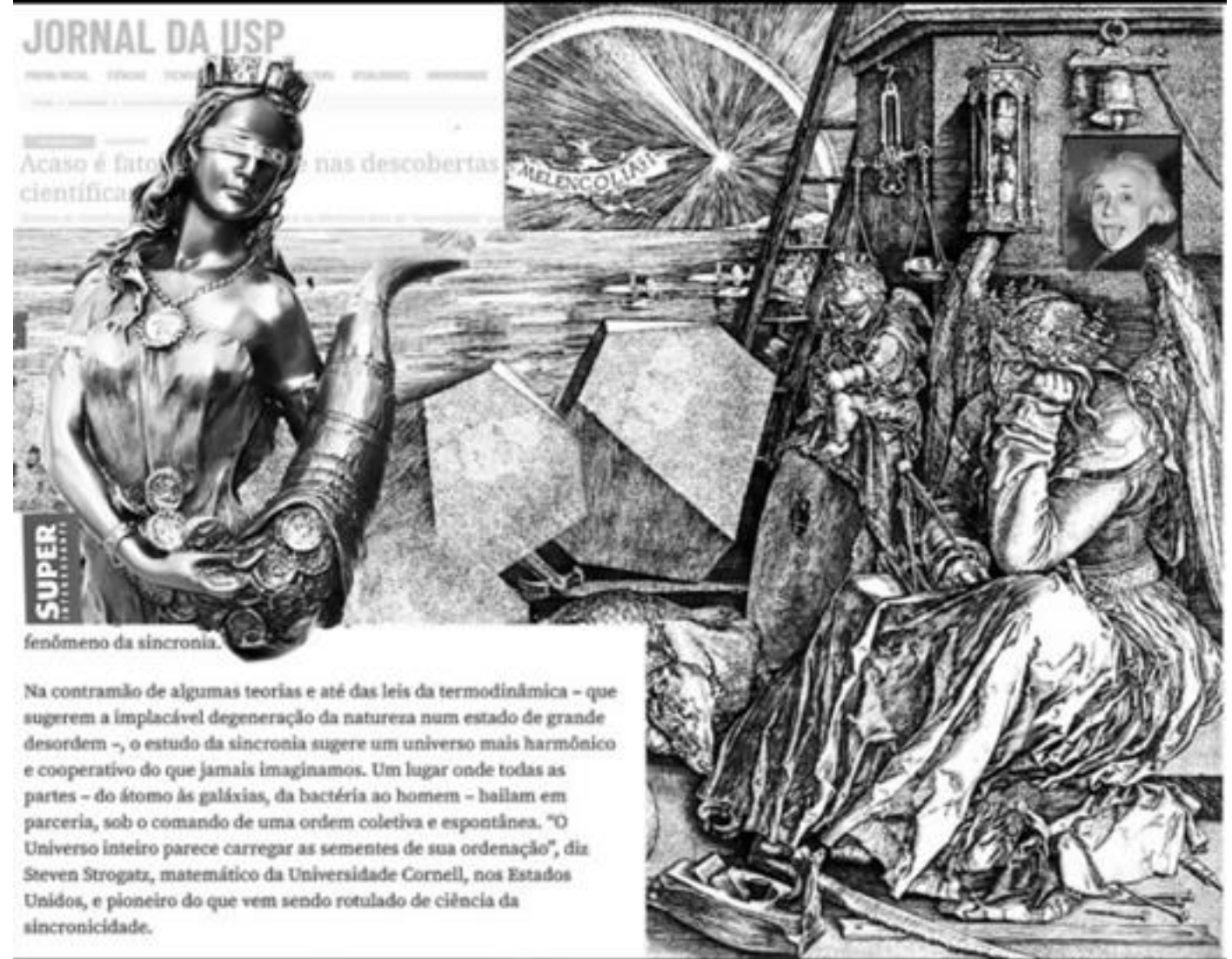


15. A morte não lança dados, tal com os demaís deuses

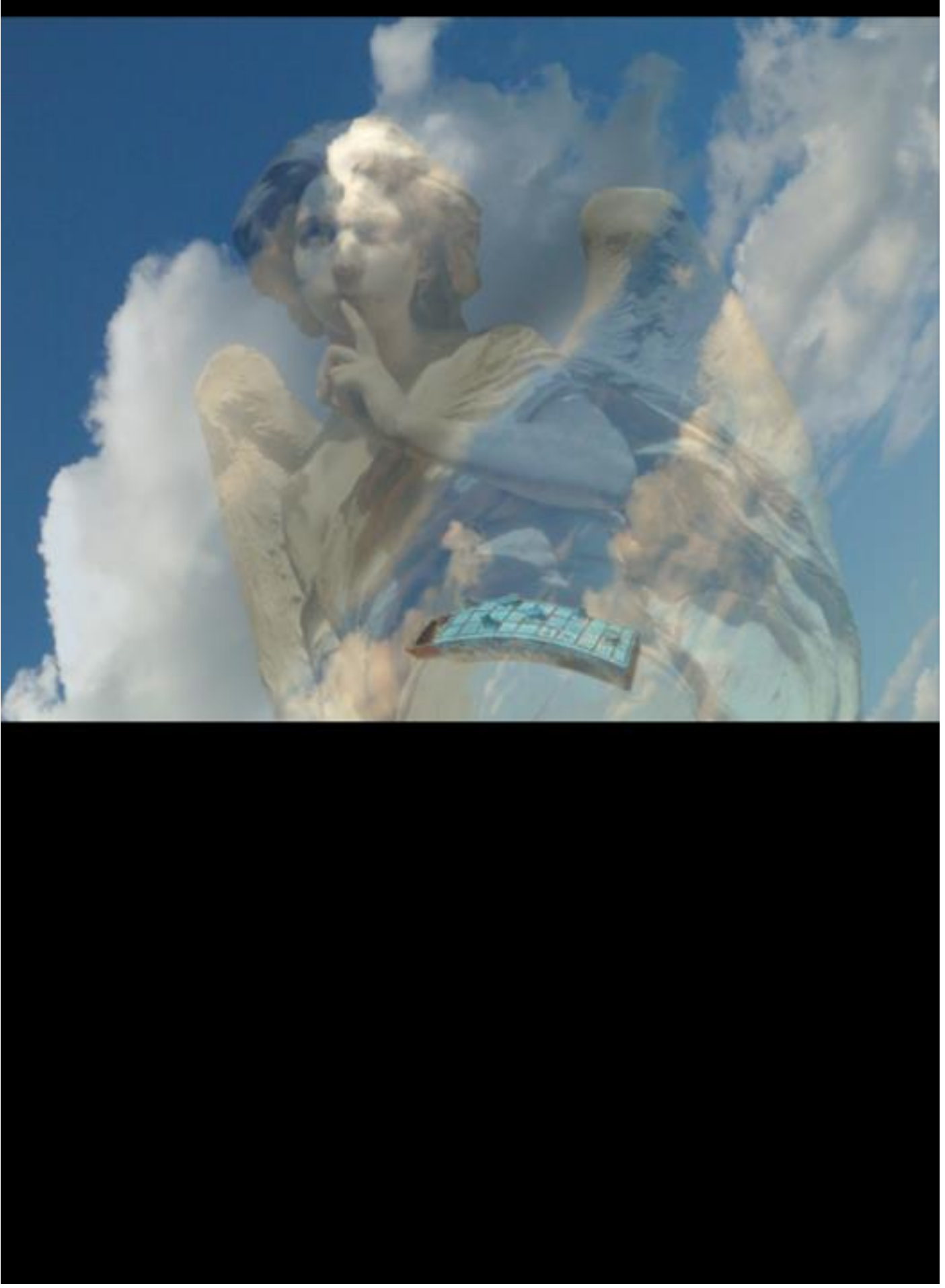


16. O deus-arquiteto de Blake não lança dados Induz humanos a se lançarem

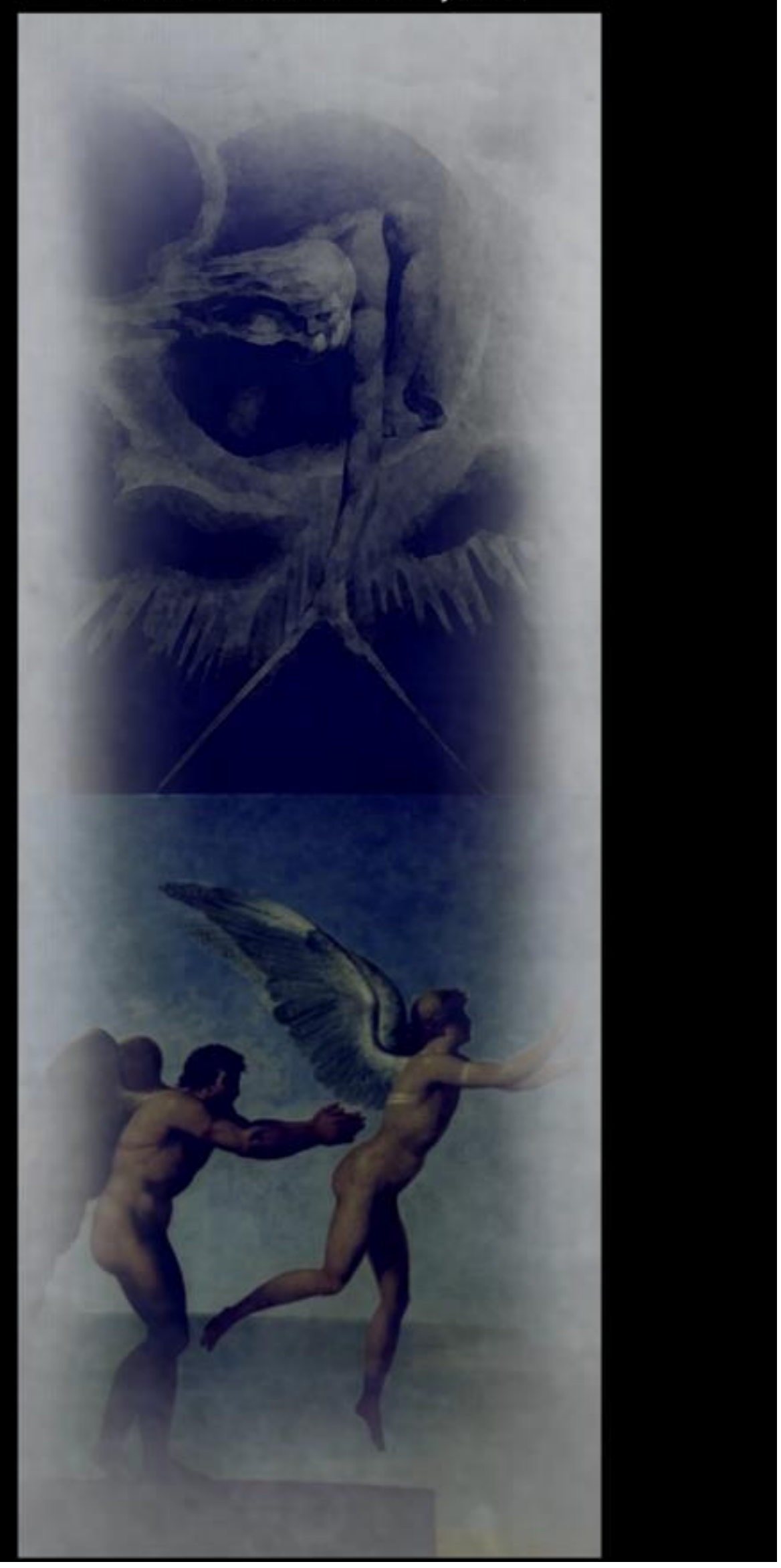




\section{Humanos sempre lanfaram dados}

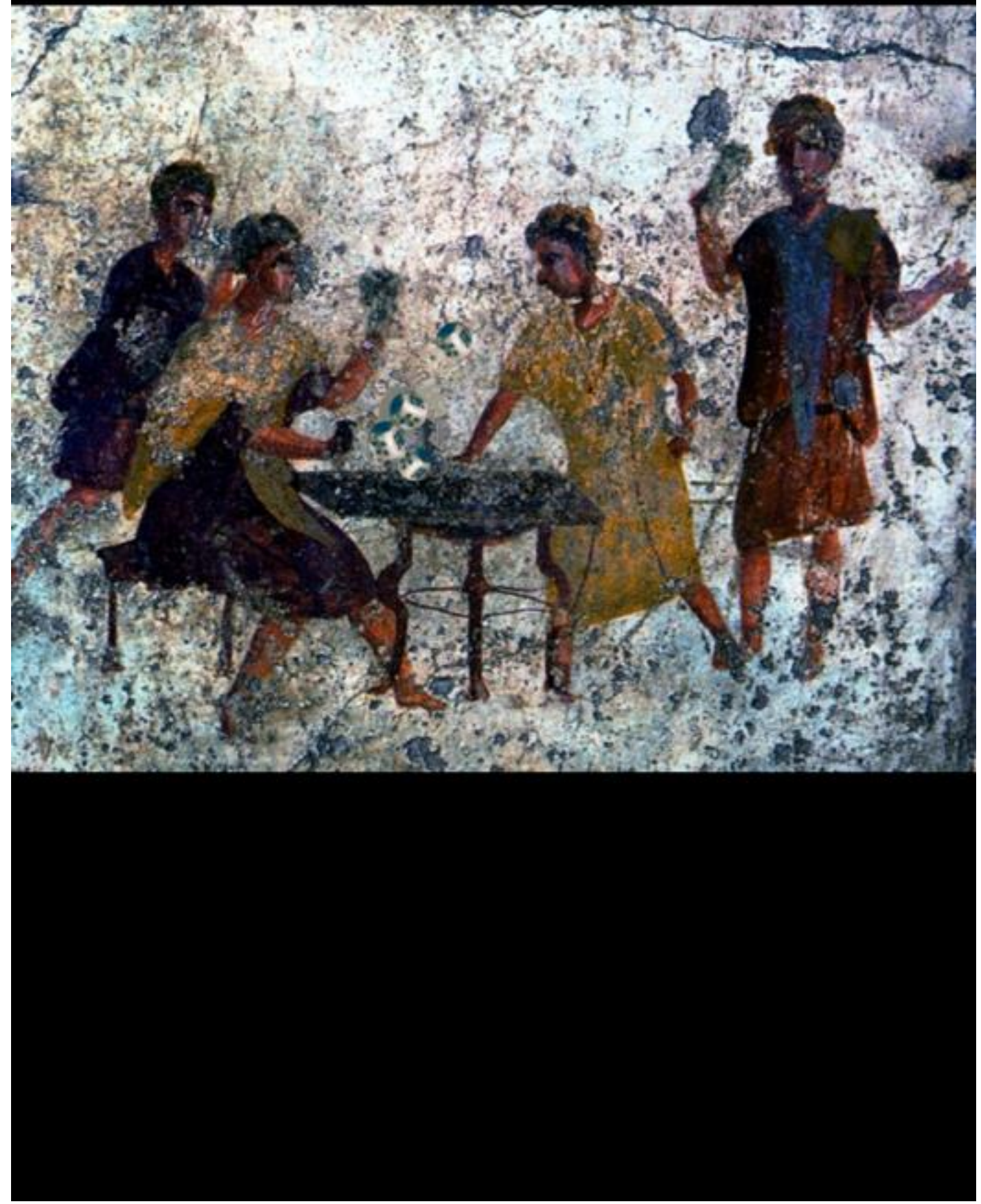


18. Pollock também lançava dados

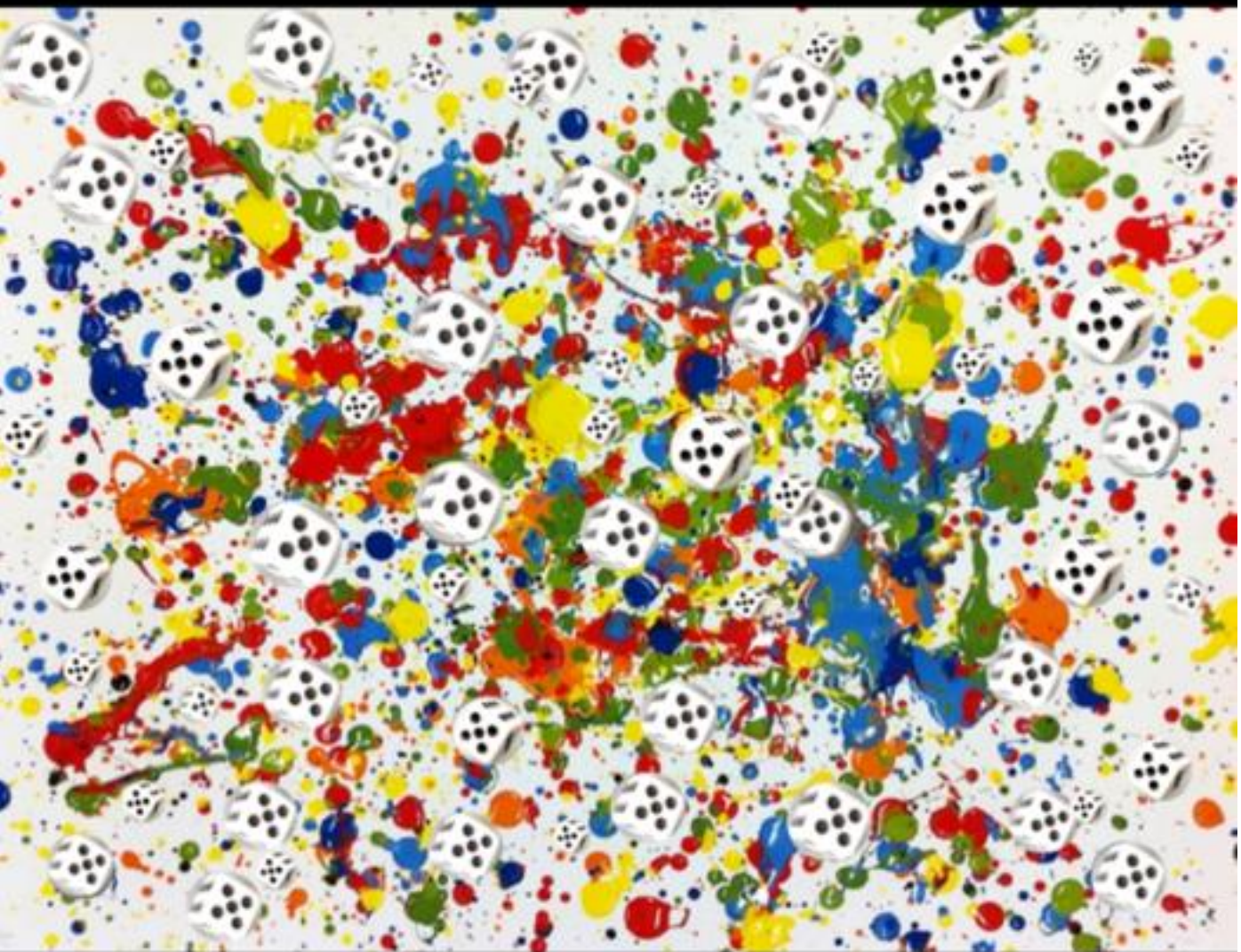


19. Pollock lançava dados de formas e cores díversas

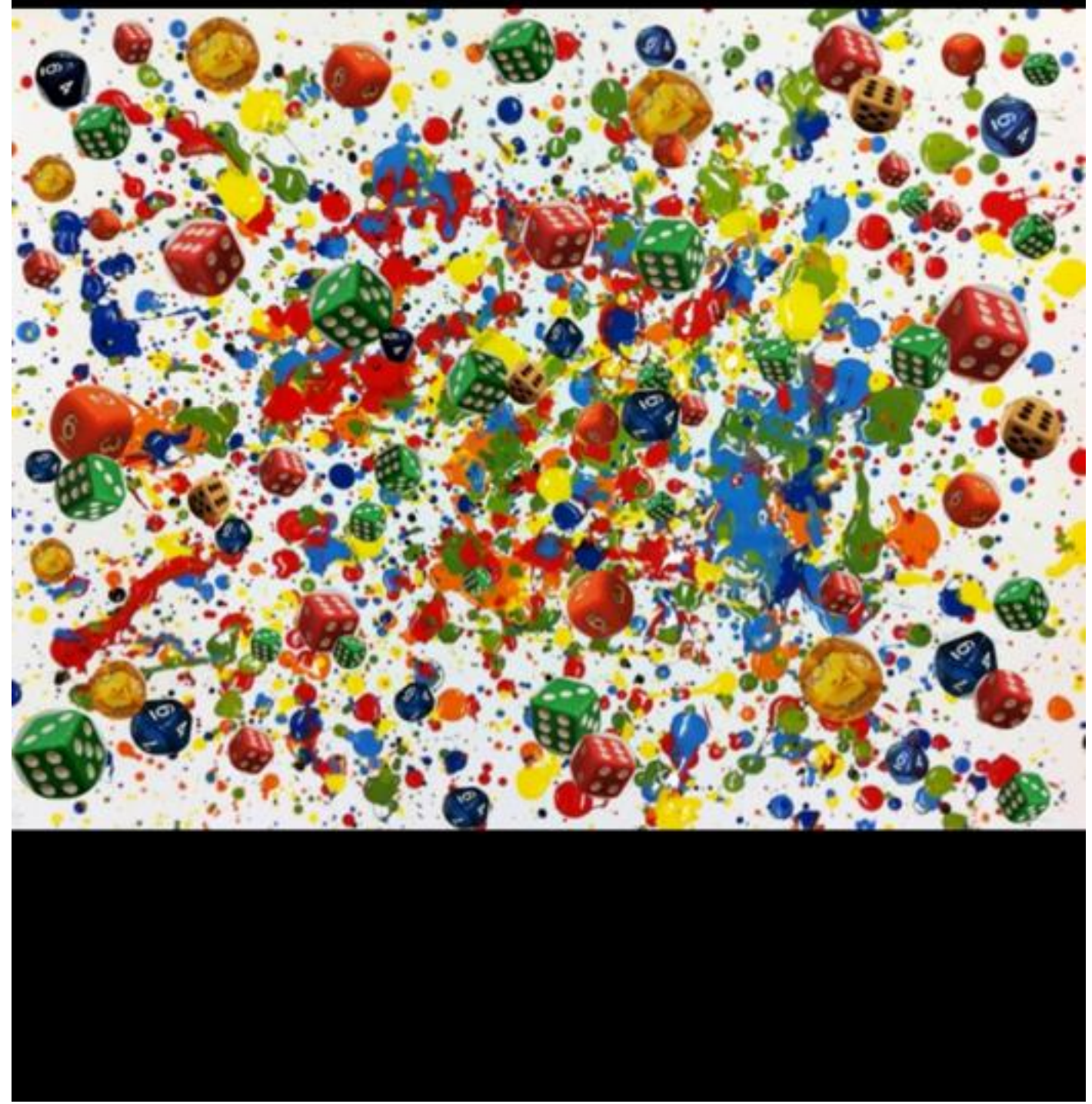


20. No primeiro día, o deus de Blake dísse: faça-se a luz! E Anna Komíssarenko a fez...

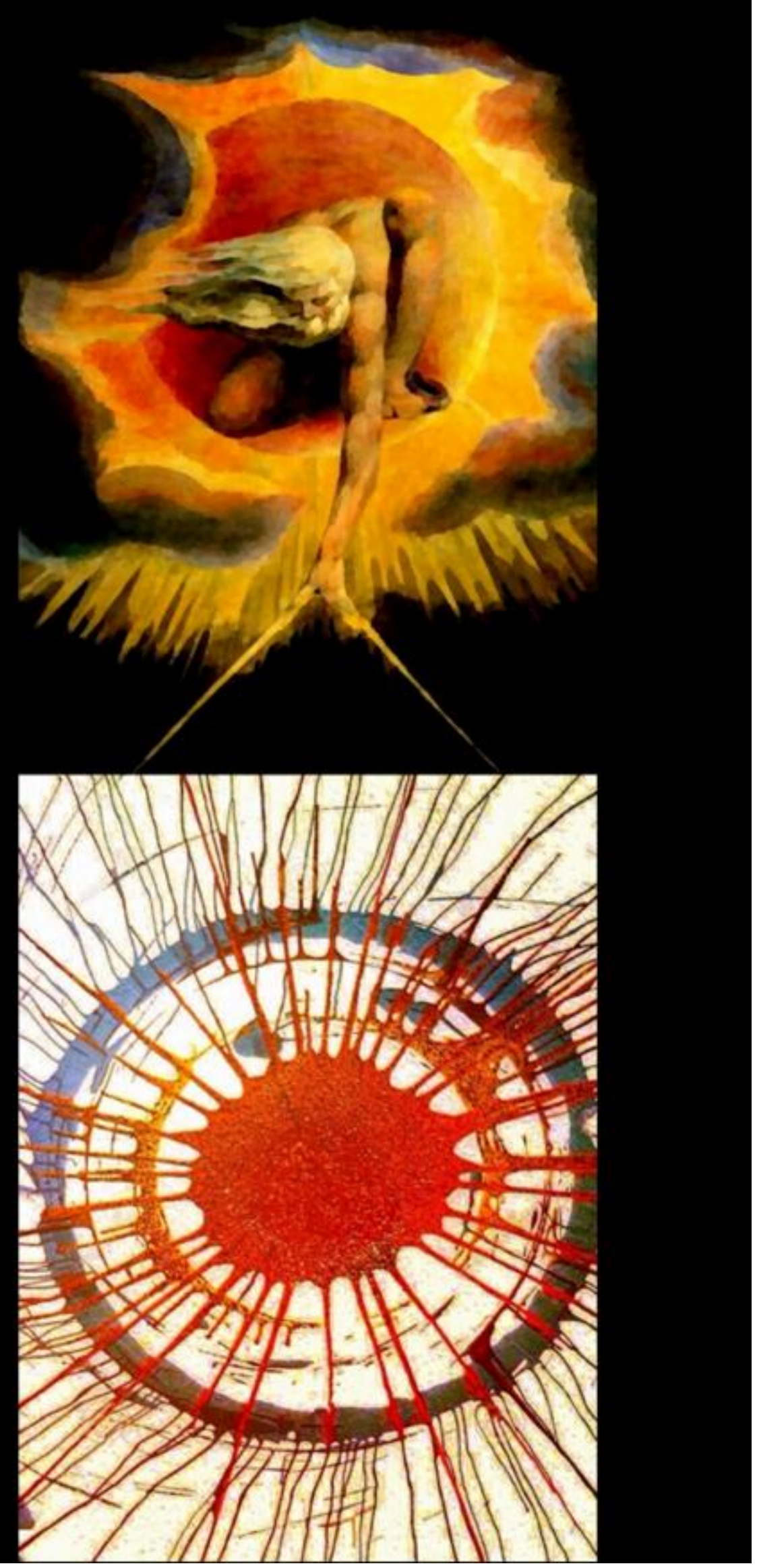


21. Mas o acaso de um vírus ocultou a luz deste acaso de Anna Komíssarenko

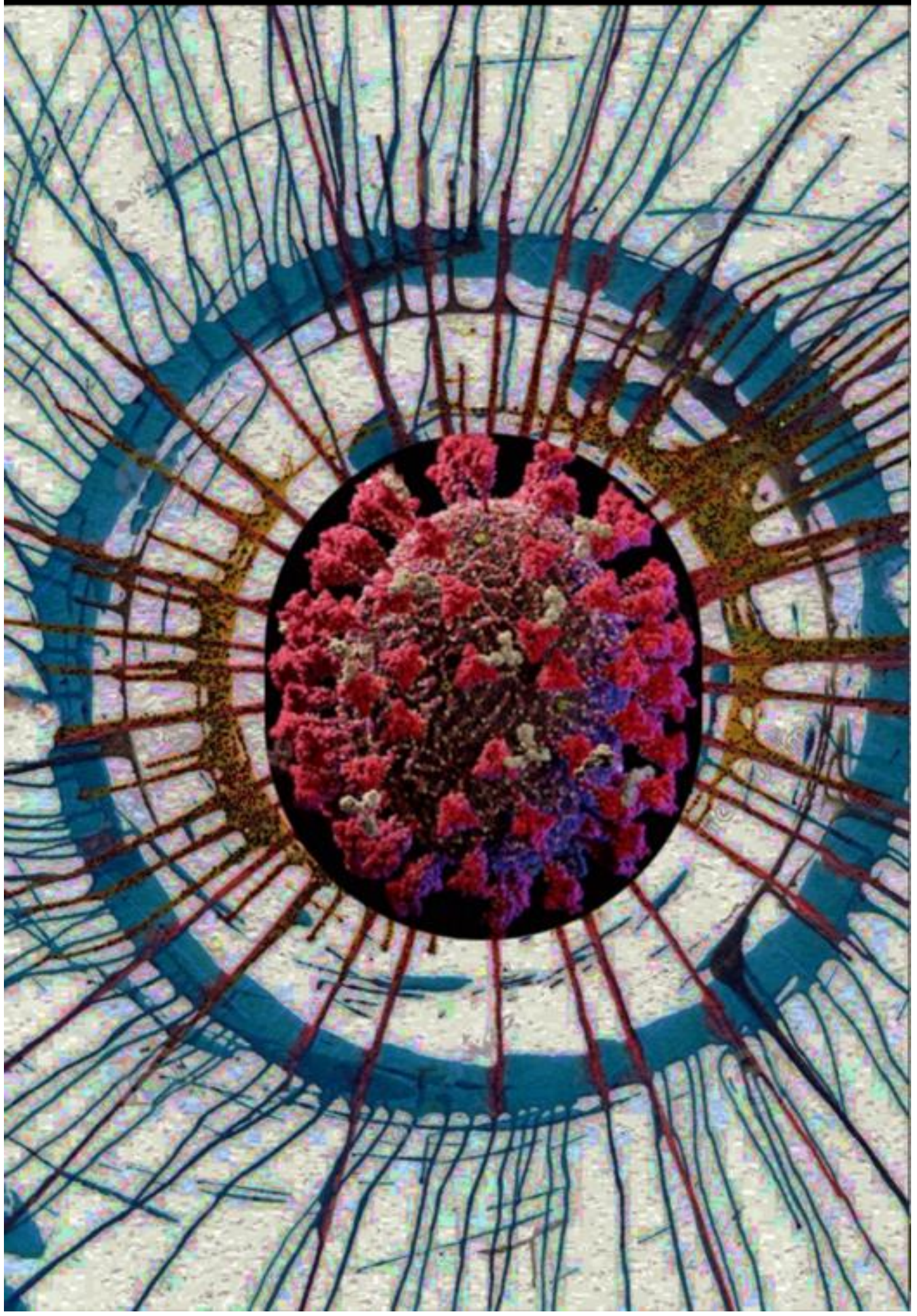




\section{E espalhou vírus váríos de maus acasos por toda a Terra}

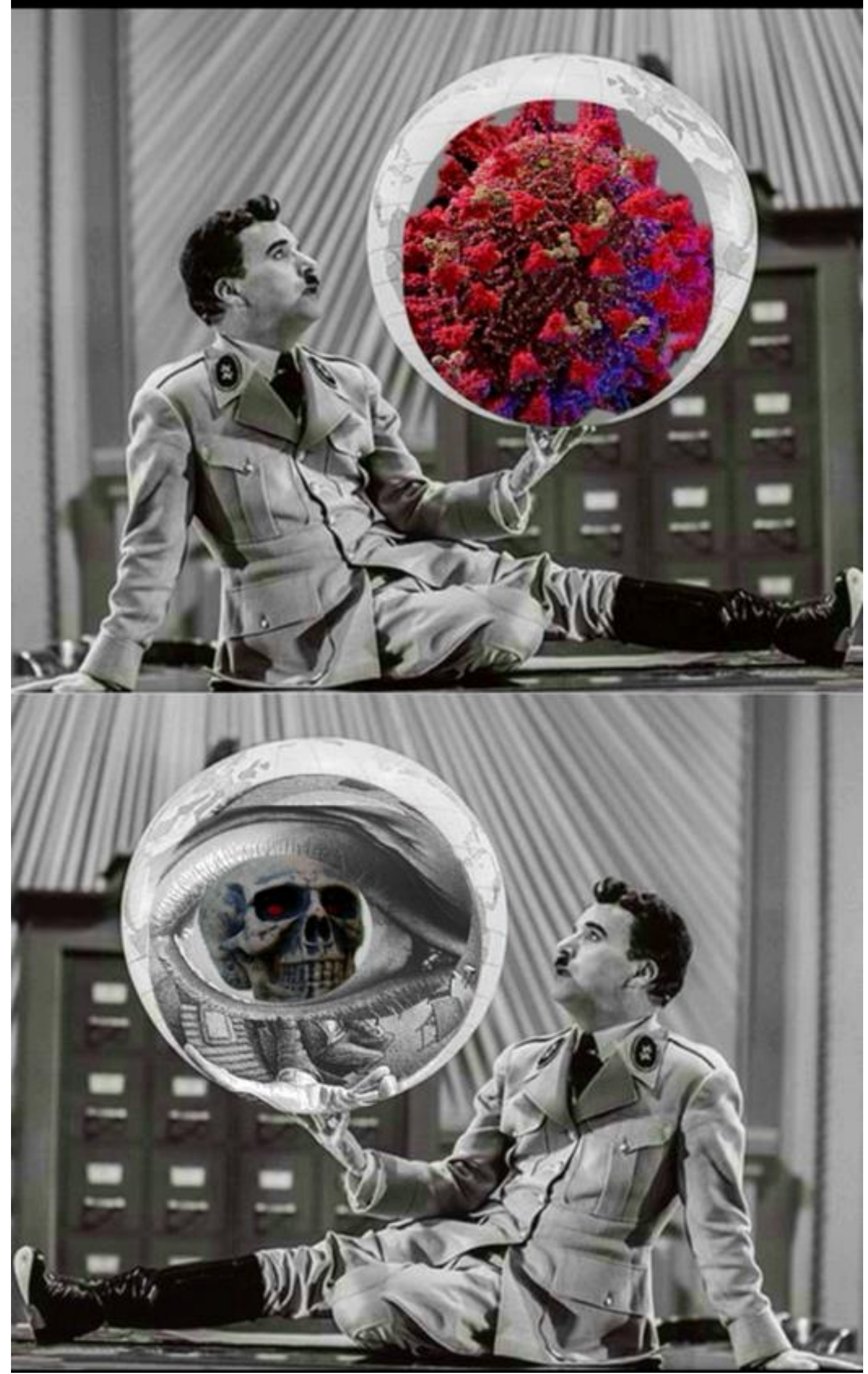


23. E terriveis monstros marinfios, sensiveis ou não a lances de dados, viralizaram suas politicas de descaso por todo o planeta

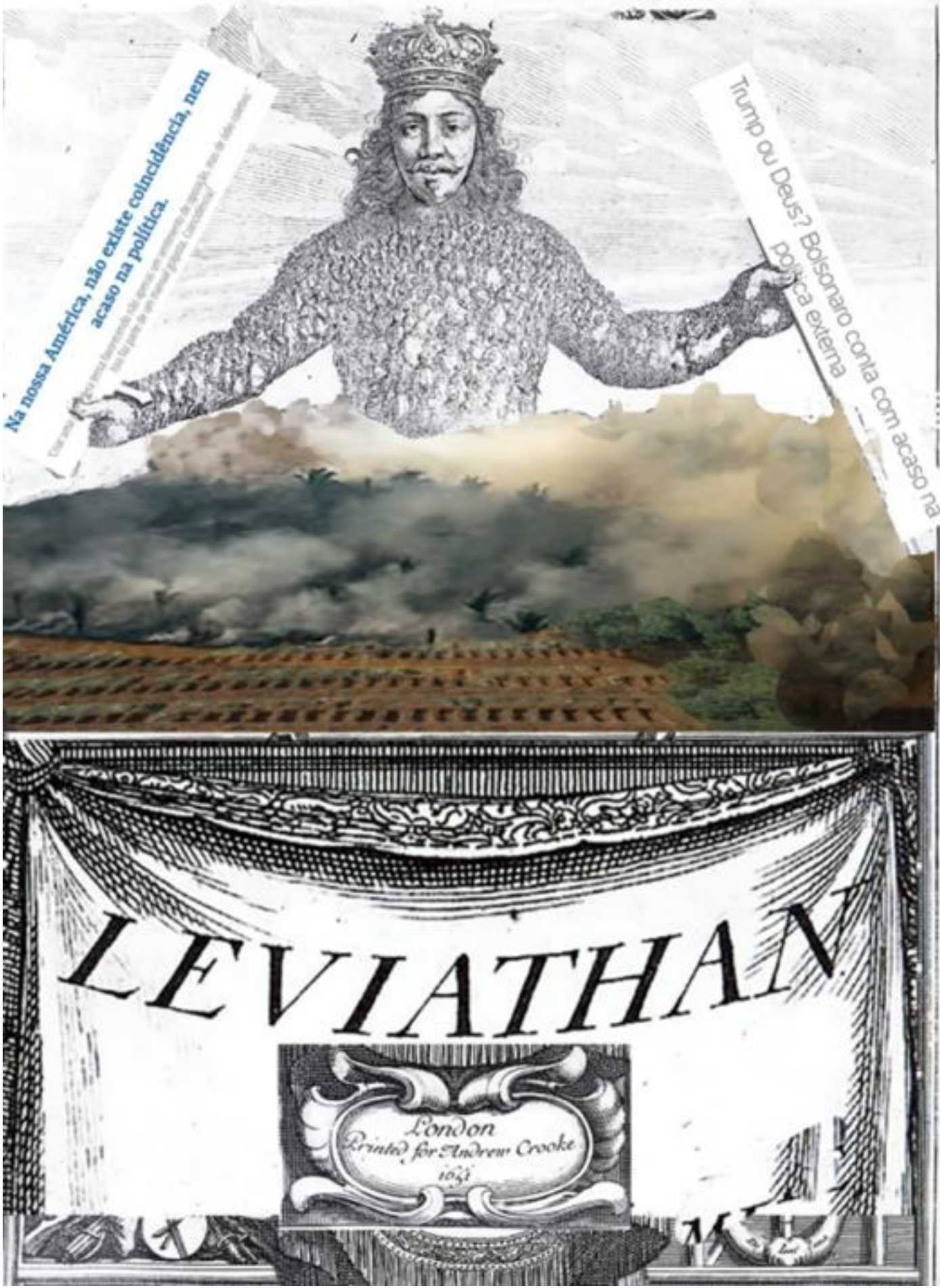


24. A deusa olimpica Deméter não lança dados, mas protege colheitas contra maus acasos

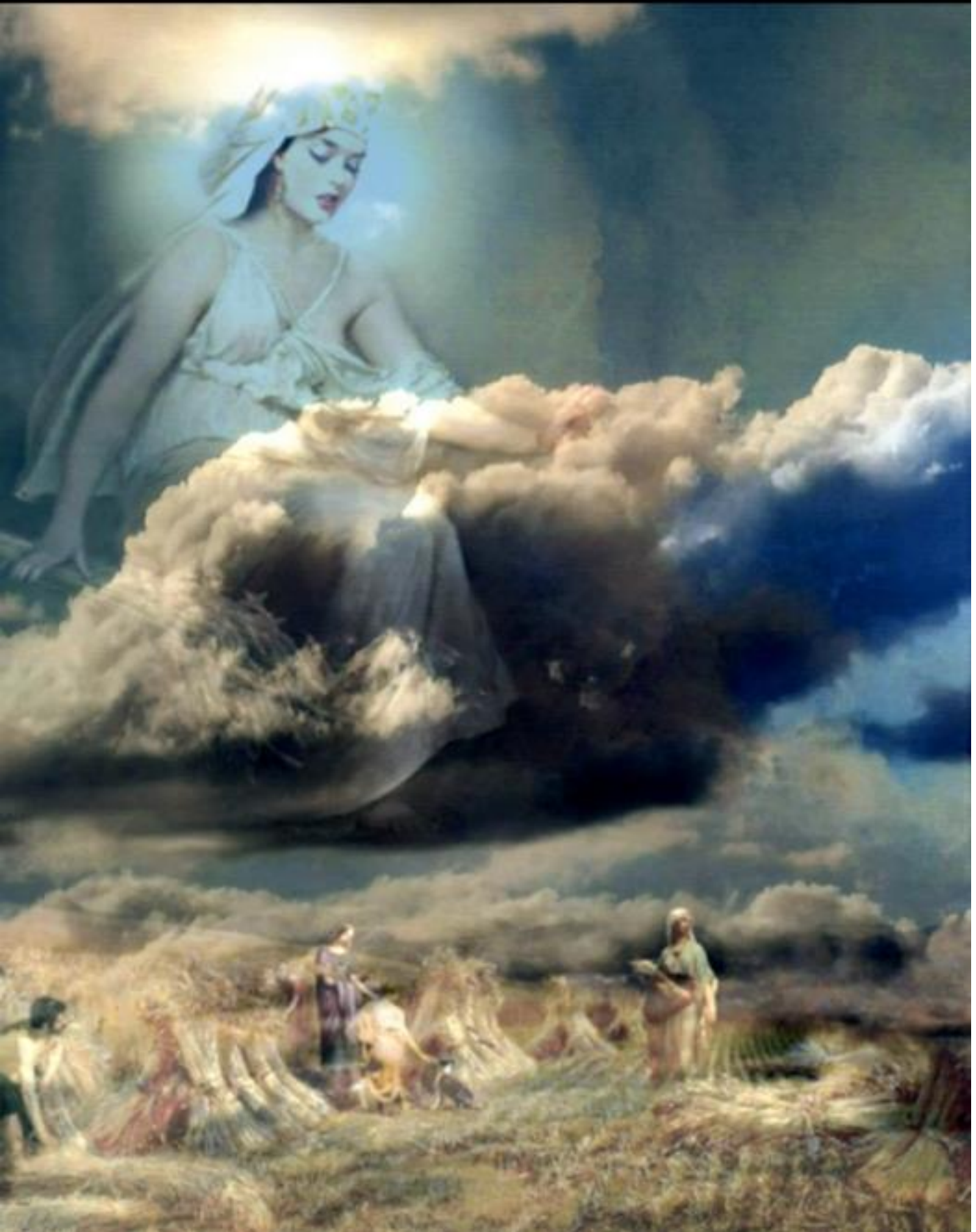


25. A deusa da Fortuna marinha de Francken não conseguíu proteger a Balsa de Medusa contra o mau acaso do naufrágio

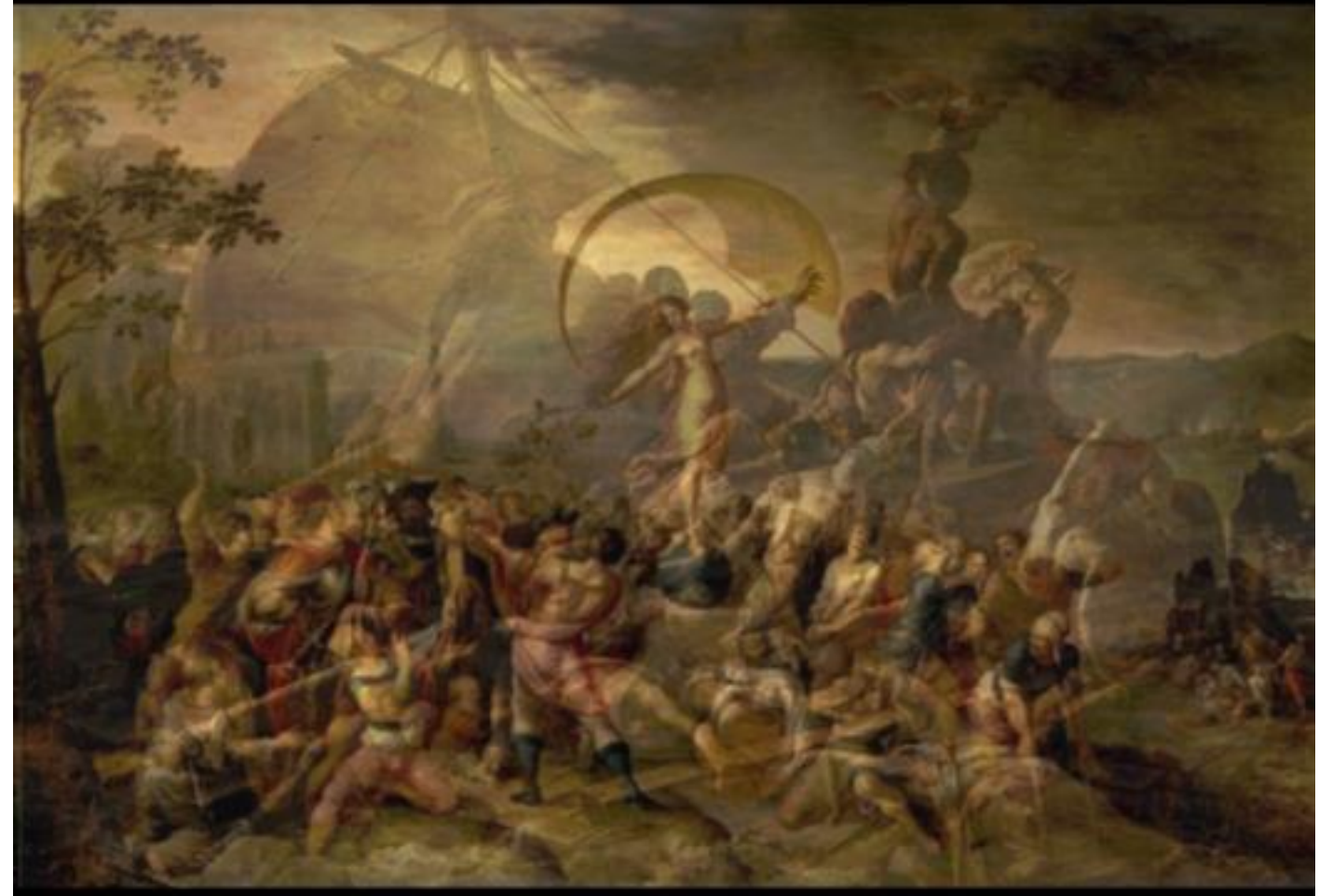


26. Insensivel às leís dos lances de dados, de olhos vendados, também a deusa da Fortuna de Kuntze não protegeu a Balsa de Medusa do naufrágío

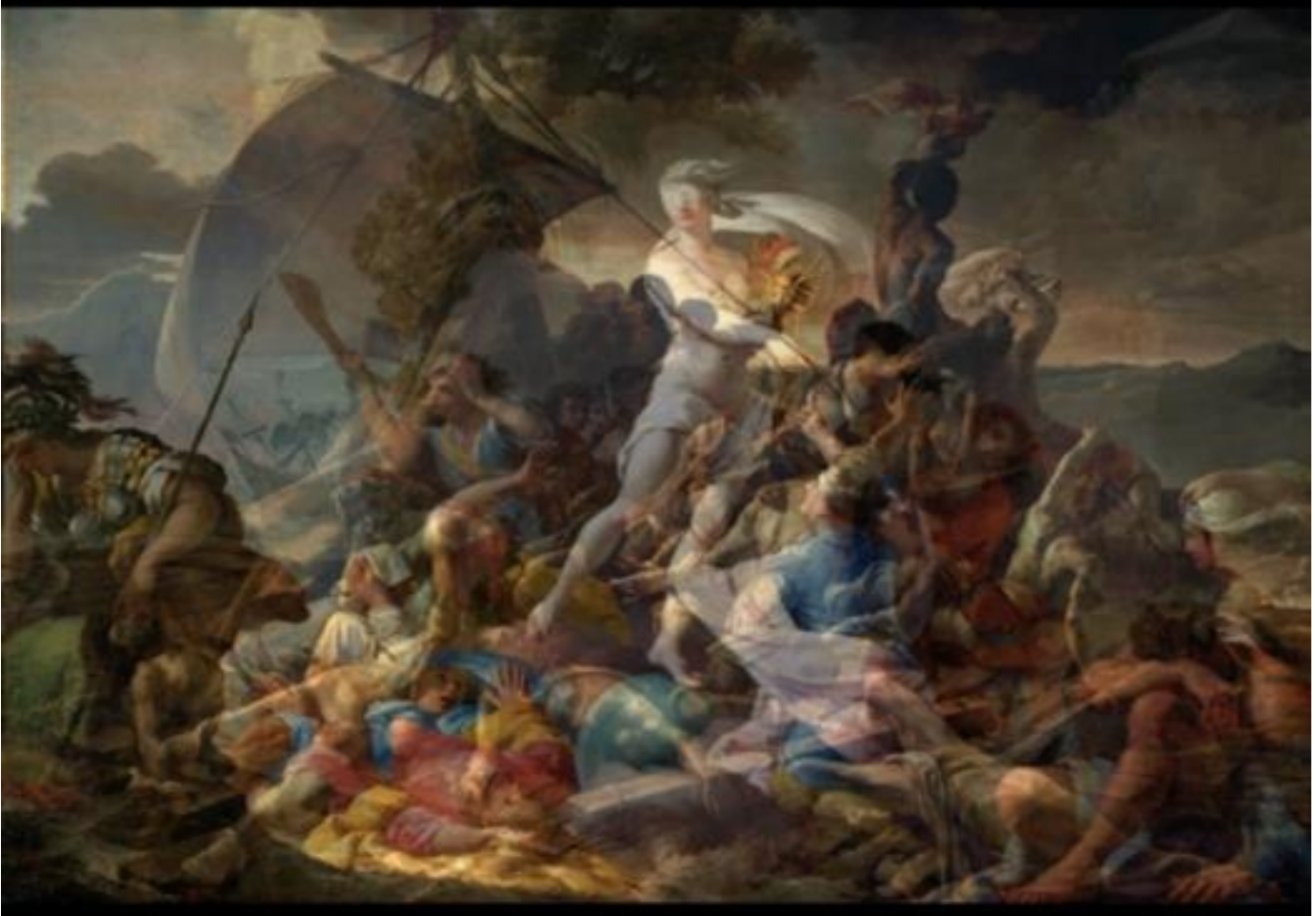




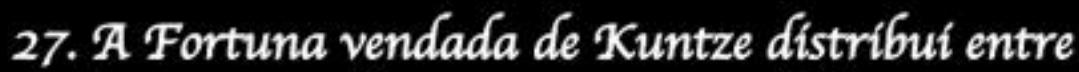
humanos ou bem-aventurangas de fortunas ou infortúnios de medusas

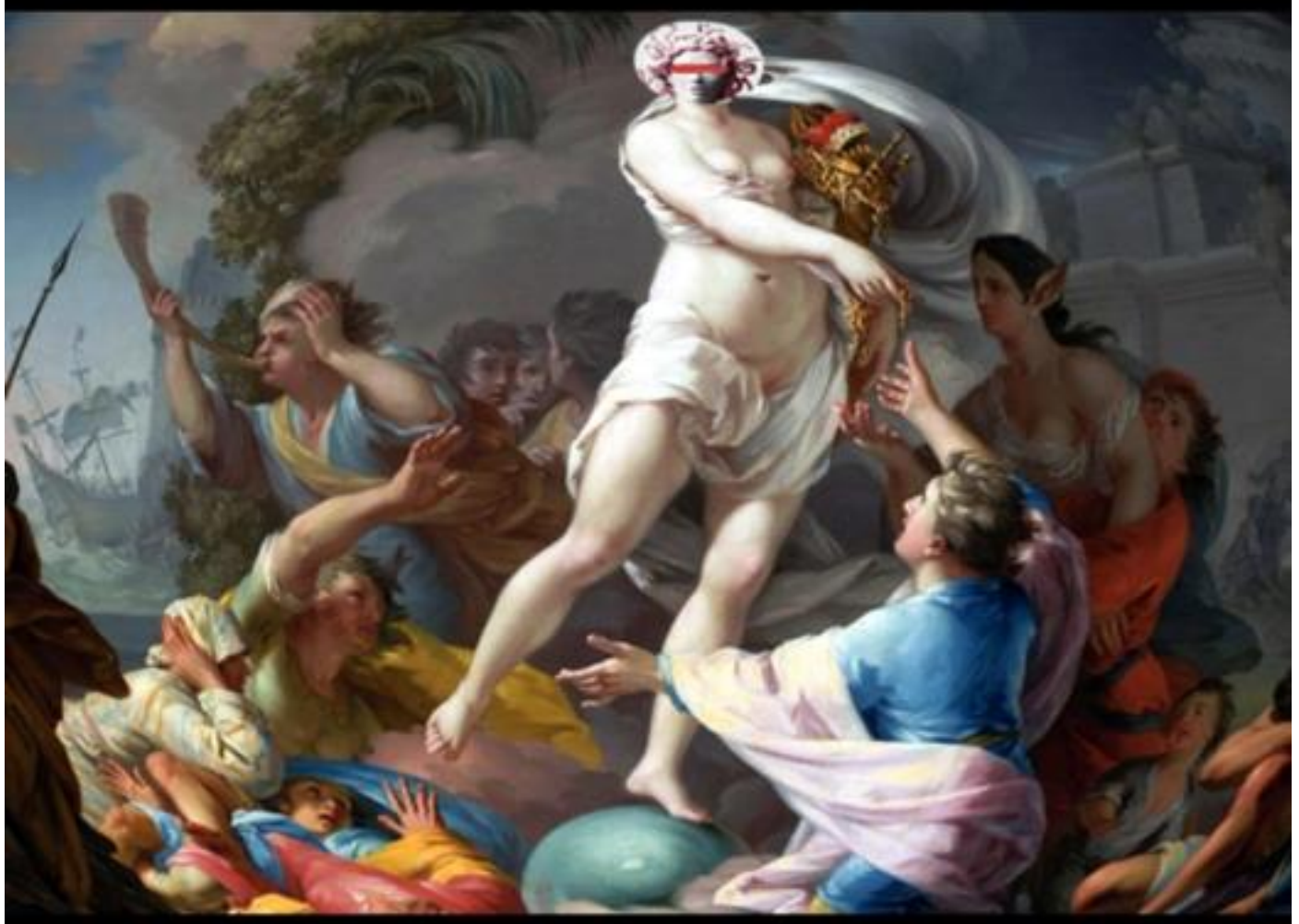


28. Afguns representantes de deuses de outros olimpos não lançam dados, mas leem os quatro destinos de humanos em cartas de tarô

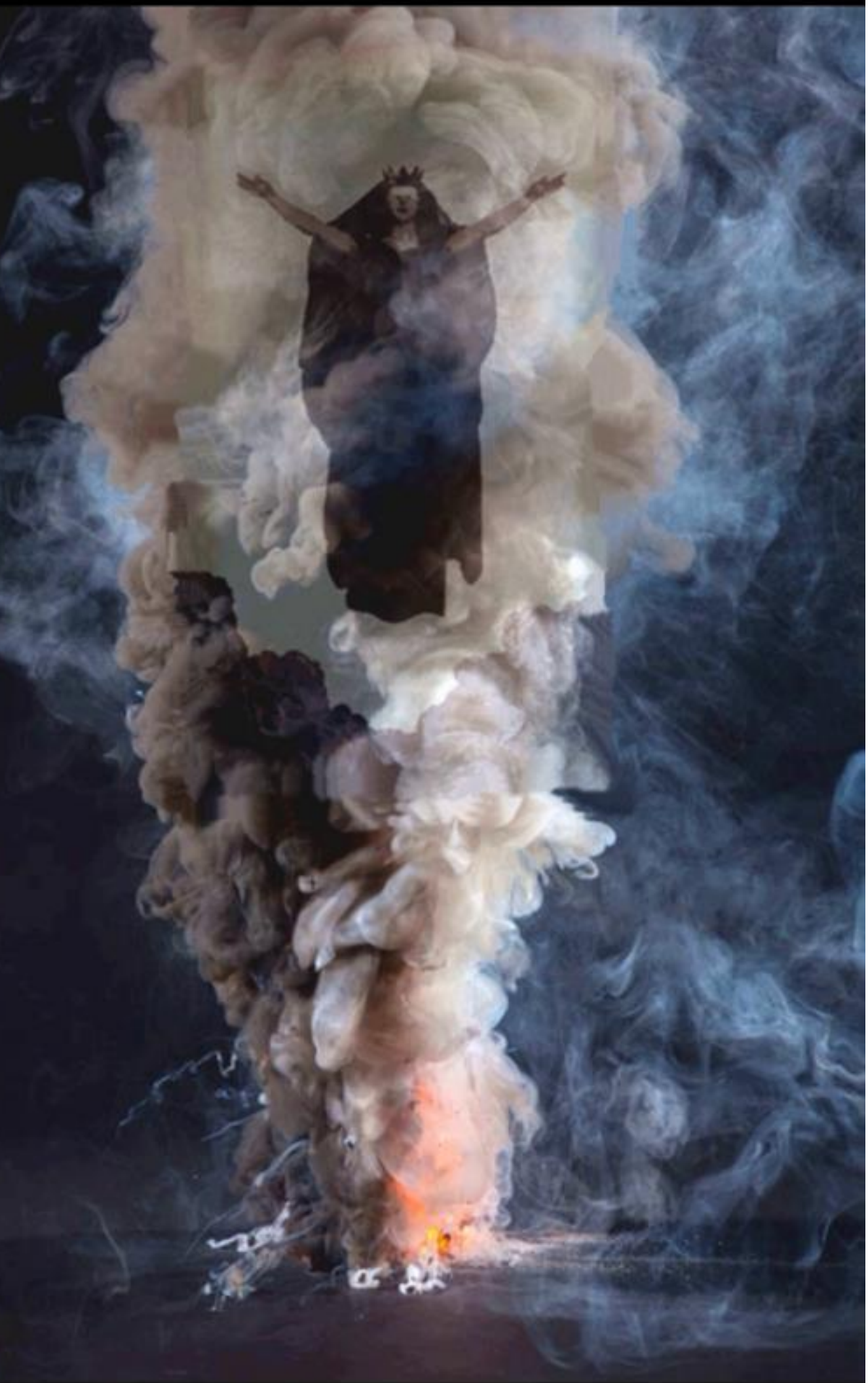


29. Uma fotografía compósita é uma probabilidade, não um acaso. A foto composita dos rostos de Wittgenstein + Arlete Brito + Antonio Miguel é um lance de dados, um rosto previsivel de ninguém

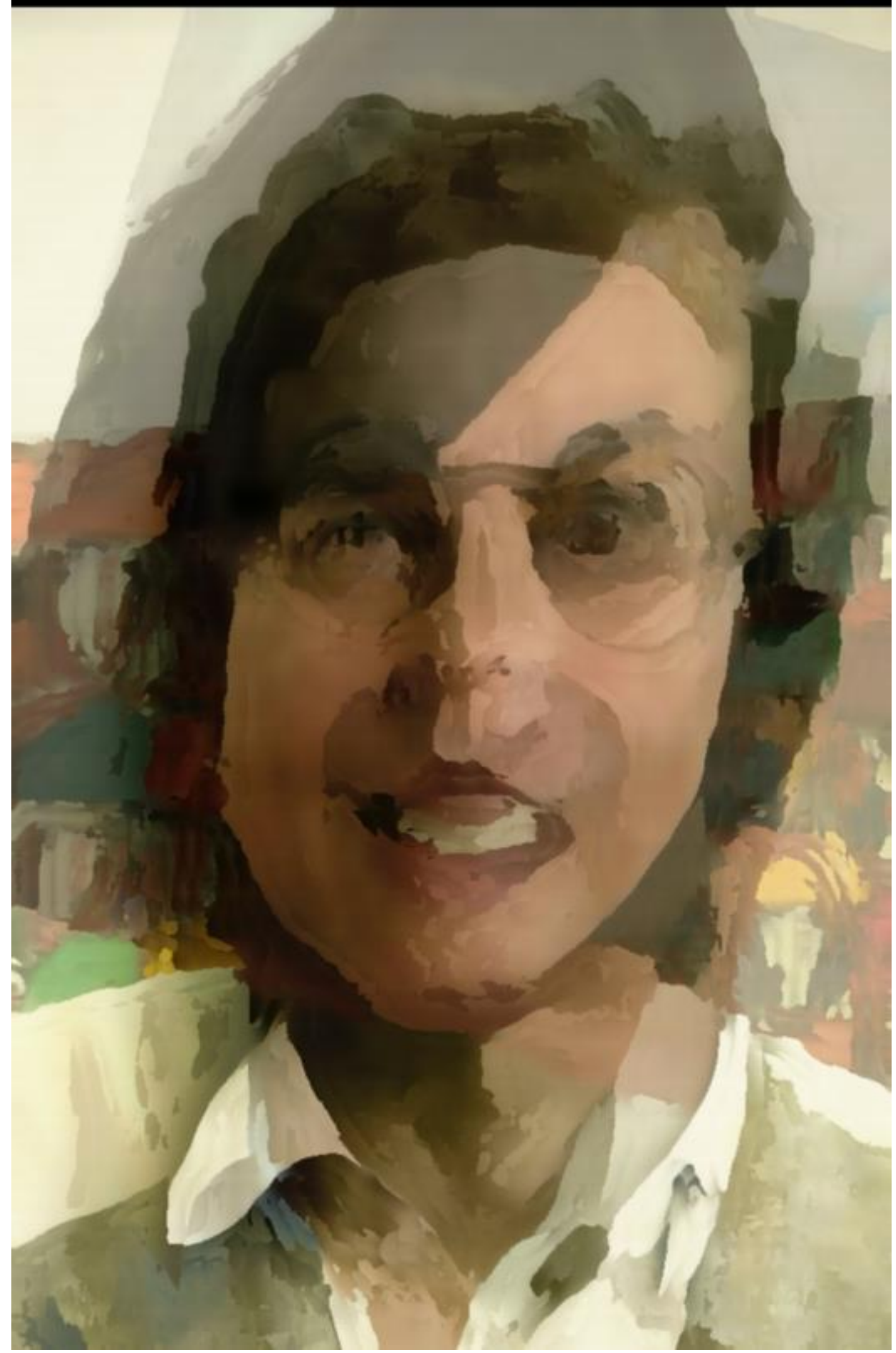


30. A foto composita de Arlete Brito + Antonio Miguel + a pintura compósita (Wittgenstein + John Lennon) de Paolozzí é um lance de dados, uma pintura compósita de um rosto previstivel de ninguém

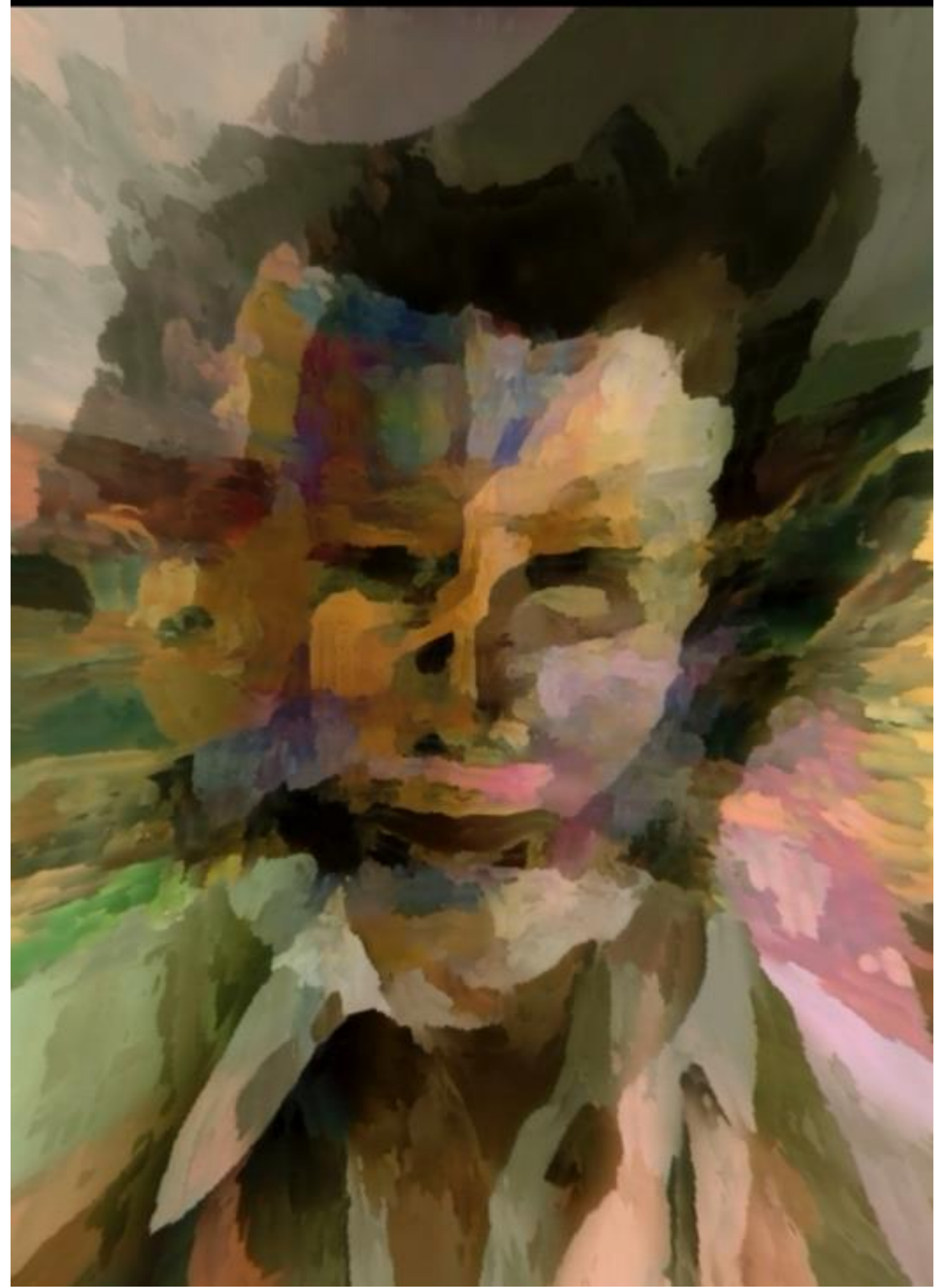


31. A deusa da Fortuna não joga dados. Deseja apenas espethar Ops, a deusa da abundância, e o mistical international Glue da Vênus alada de Yves KKlein

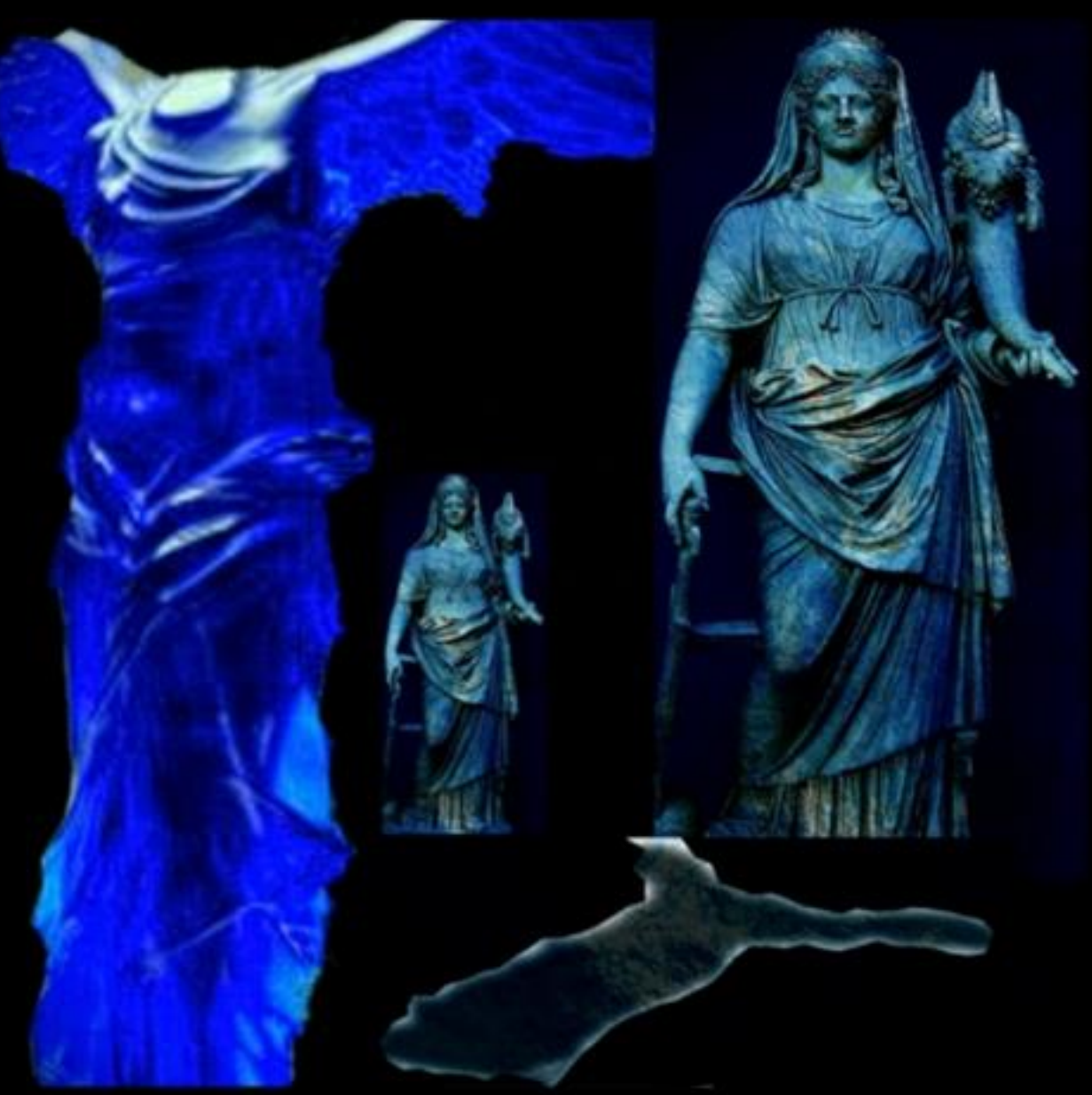


32. Penas não lançam dados. Flutuam ao acaso... 
C 0

M O

B 0

$\begin{array}{llll}\mathcal{L} & \mathcal{A} & S\end{array}$

$\begin{array}{llll}C & \circ & \mathcal{L} & O\end{array}$

R I

D

$\mathcal{D} \quad \mathcal{A} S$

$\mathcal{D} \quad \mathcal{E}$

S $\mathbb{A}$

$\mathcal{B} \quad 0$

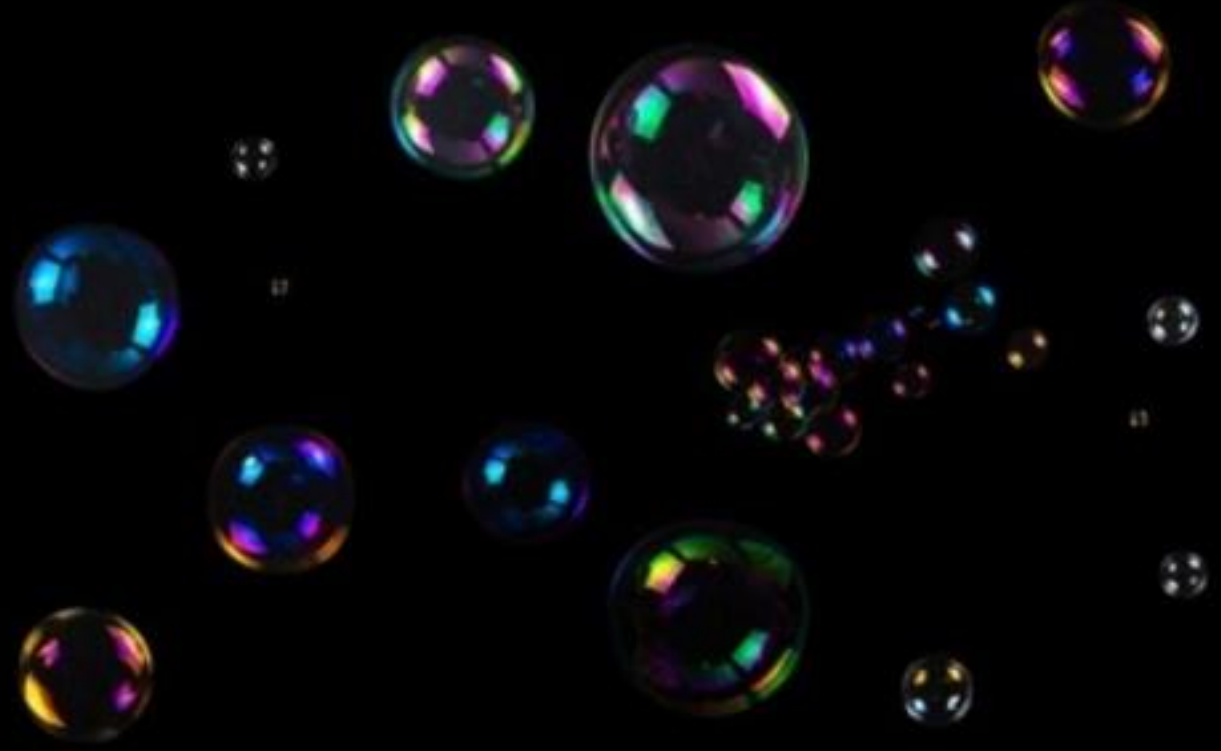


NOTA 1 - Foto-imagem produzida a partir de duas fotografias: 1) a do projeto gráfico intitulado $O$ anciào dos dias (The Ancient of Days) do poeta, tipógrafo e pintor ingless William Blake (1757-1827) para a capa do seu livro Europa uma profecia, publicado em $1794 ; 2$ ) a de fotografias de dados cúbicos do arquivo de fotografias dos autores. A referência que fazemos ao ancião da foto-imagem de Blake como deus-arquiteto tem base no fato de que o mistico Blake o nomeava Urizen, descrevendo-o ou desenhando-o como um velho barburdo empunhando, às vezes, quatro livros representativos das leis que ele impỏe à humanidade e, outras vezes, carregando instrumentos geométricos de trabalho de um arquiteto do século I8. Assim, o nosso Urizen-deus-arquiteto de Blake é um deus triplamente normativo - juridicamente normativo, geometricamente normativo $\mathrm{e}$ nomoteticamente normativo, quer no sentido determinista, quer no sentido probabilistico - sendo, portanto, legítimo retratá-lo, nåo como um deus casual, mas como um deus que lança dados. A foto-imagem foi produzida com base nos recursos digitais possibilitados pelo software Movavi Photo Editor 6 for Mac Personal. Fonte da imagem e das informaçōes: (https://en.wikipedia.org/wiki/The_Ancient_of_Days).

NOTA 2 - Foto-imagem produzida a partir de duas fotografias: a da imagem $O$ ancião dos dias de William Blake, a que já nos referimos na Nota 1; a de uma fotografia, disponivel na internet, de um dado de osso, utilizado pelos antigos romanos. Esta última passou por um processo de alteração, antes de compor a imagem final. A foto-imagem foi produzida com base nos recursos digitais possibilitados pelo software Adobe Photoshop.

Fonte:(https $/ /$ br.pinterest.com/pin/337558934571002440/2amp_client_id=CLIENT_ID() \&mweb_unauth_id=\&simplified=true).

NOTA 3 - Foto-imagem produzida a partir de duas fotografias: 1) a da imagem $O$ ancião dos dias de William Blake, a que já nos referimos na Nota $1 ; 2$ ) a de fotografias das duas faces de uma moeda em bronze em circulação em Roma, no século III d.C. A moeda foi cunhada durante o reinado do imperador romano Gordiano III (238-244 d.C) - mais conhecido nos paises de lingua portuguesa como Marco Antonio - e retrata, em uma de suas faces, a deusa grega do acaso Tique - e, na face oposto a mesma deusa e o imperador Marco Antonio, olhandose face a face. A foto-imagem foi produzida com base nos recursos digitais possibilitados pelo software Movavi Photo Editor 6 for Mac - Personal. Fonte:(https:/pt.wikipedia.org/wiki/Tique_(mitologia)"\#/media/Ficheiro:BronzeGordian_III_and_Tranquillina-1I parthica-singara_AE33_BMC_7.jpg).

NOTA 4 - Esta foto-imagem foi produzida a partir da reportagem lida em The Intercept Brasil. Ainda foram utilizadas, da internet, as imagens de uma roleta e da igreja universal da cidade de Natal-RN. Essas duas fotografias foram alteradas antes de compormos a foto-imagem final, da qual também fazem parte outras duas fotos - a da cruz e a das moedas. A produção digital ocorreu com o software Adobe Photoshop.

Fontes:(https:/theintercept.com/2019/12/24/igreja-instituicao-por-acaso-religiosa-kellybrown-douglas/);(https://www.elo7.com.br/painel-redondo-sublimado-roleta-cassino$160 \times 160 \mathrm{~cm} / \mathrm{dp} / 11 \mathrm{AC} 2 \mathrm{Cl}$ );(https://asemananews.com.br/2017/11/24/o-natal-de-2017comeca-com-a-inauguracao-do-templo-da-igreja-universal-porque-jesus-cristo-e-o-senhordiz-grecal). 
NOTA 5 - Foto-imagem produzida a partir de duas fotografias: 1) a da imagem $O$ anciầo dos dias de William Blake, a que já nos referimos na Nota 1 ; 2) a de fotografias das duas faces de uma moeda em bronze em circulaçào em Roma, no século III d.C. A moeda foi cunhada durante o reinado do imperador romano Gordiano III (238-244 d.C) - mais conhecido nos paises de lingua portuguesa como Marco Antonio - e retrata, em uma de suas faces, a deusa grega do acaso - Tique - $e$, na face oposto a mesma deusa e o imperador Marco Antonio, olhando-se face a face. A foto-imagem foi produzida com base nos recursos digitais possibilitados pelo software Movavi Photo Editor 6 for Mac-Personal.

Fontes:-(https://pt.wikipedia.org/wiki/Tique_(mitologia)\#/media/Ficheiro:BronzeGordian_III_and_Tranquillina-11 parthica-singara_AE33_BMC_7.jpg).

NOTA 6 - Esta clássica representaçảo de lemanjá ressalta o sincretismo religioso que a ela atribui uma identidade correspondente a outras santas da religião católica, quais sejam: Nossa Senhora de Candeias, Nossa Senhora dos Navegantes, Nossa Senhora da Conceição, Nossa Senhora da Piedade e a Virgem Maria. Tal sineretismo remonta a um periodo em que o culto de deuses de religioes africanas era proibido no Brasil. Os dados brancos fazem parte do acervo de imagens dos autores. A manipulaçłlo digital da foto-imagem foi realizada com Adobe Photoshop. Fonte: (https://www.significados.com.br/iemanja).

NOTA 7 - Invertendo o sincretismo religioso da foto-imagem da Nota 5, esta fotoimagem transgride a identidade catolicizada de lemanjâ, substituindo o seu rosto branco de santas católicas pelo rosto negro da estátua de lemanjá da Praia de Camburi, em Vitória - Espirito Santo. Fonte; (https $/ /$ www.significados.com.br/iemanja/); (https://pt,wikipedia.org/wiki/lemanja).

NOTA 8 - Ambas as fotografias - a da estátua que repesenta o Cristo e a do fundo fazem parte do acervo fotográfico de um dos autores. Já a foto dos dados que compōe esta foto-imagem está disponivel no site abaixo referido. A produçăo digital ocorreu com o software Adobe Photoshop. Fonte:(https:/br.freepik.com/fotospremium/dados-azuis-sobre-fundo-vermelho-close-up_6854247.htm).

NOTA 9 - A fotografia da estátua de Lakshimi faz parte do acervo fotográfico de um dos autores. O fundo da imagem ế a explosão de uma supernova registrada, por acaso, por um astrônomo. Os dados que dançam nesta foto-imagem são os mesmos da foto-imagem a que fizemos referência na Nota 6. A produçầo digital ocorreu com o software Adobe Photoshop. Fonte: (https://exame.com/ciencialastronomo-registra-poracaso-explosao-de-supernova-em-gravacao/).

NOTA 10 - A foto da estátua de Buda faz parte do acervo fotográfico de um dos autores. Essa foto passou por uma transformação com edição digital no Adobe Photoshop. Os dados antigos que foram utilizados nesta foto-imagem estão disponiveis no site: (http $/ /$ boardgamemaniacs.blogspot.com/p/blog-page_26.html).

NOTA 11 - A imagem de Anúbis pesando o coração de um morto para saber qual será seu destino após a morte faz parte do Livro dos Mortos, dos egipcios antigos, acessivel no link abaixo referido. Ela foi alterada com a inserç̃o da imagem de um dado, no lugar do fiel da balança. A produçào digital foi realizada com o software Adobe Photoshop.

Fonte: (https://www,infoescola.com/civilizacao-egipcia/livro-dos-mortos/) 
NOTA 12 - Foto-imagem produzida a partir de duas fotografias: 1) a da imagem $O$ anciào dos dias de William Blake, a que já nos referimos na Nota $1 ; 2$ ) a da mais precisa imagem-modelo em 3D construida do coronavirus em maio de 2020, com base em pesquisas até então realizadas por virologistas e especialistas em biociência. A imagem foi produzida pelo estúdio de visualizaçăo biomédica Visual Science, com base em técnicas de bioinformática usadas em pesquisas de medicamentos. Nela, as partes em cores vibrantes representam as proteinas codificadas pelo genoma e as partes em tons de cinza representam as estruturas retiradas pelo virus da cellula hospedeira. Tal imagem e as informaçđes aqui transmitidas acerca dela estão disponiveis no site abaixo referido. Já a foto-imagem que utilizamos nesta fotomontagem foi produzida a partir de fotografias que fizemos de cenas do filme relativo a essa matéria que pode ser acessado no link do youtube abaixo referido e de suas posteriores manipulaçôes com base nos recursos digitais possibilitados pelo software Movavi Photo Editor 6 for Mac-Personal. Fontes:(https:/www, uol.com.br/vivabem/noticias/redacao/2020/05/15/coronavirus-3dprecisa.htm);(https $J /$ www.youtube.com/watch?time_continuc $=24 \&$ vey6VC9UqAXHA\& feature =emb_logo).

NOTA 13 - Foto-imagem produzida a partir de duas fotografias: 1) da carta $\mathrm{X}$ do tarô. (Roda da Fortuna ou Roda do Destino), acessivel no site abaixo referido; 2) a da mais precisa imagem-modelo em 3D construida do coronavirus em maio de 2020 a que fizemos referência na Nota 12. Segundo a compilaçăo feita por Riemma, acessivel no site abaixo referido, essa carta do tarô representa simbolicamente "os ciclos sucessivos na natureza e na vida humana; as fases da manifestaçào, o movimento de ascensåo e de declinio; a mobilidade das coisas, as influências lunares e mercurianas". Esta matéria também nos esclarece que "uma das alegorias mais antigas e populares, a imagem que reproduz o Arcano $\mathrm{X}$ causa uma impressåo estranha ao observador contemporaineo. Isto se deve ao fato de que nos últimos séculos a iconografia do tema tornou-se puramente verbal: qualquer um entende o conceito de "roda do destino", mas dificilmente se faz dela uma representação visual. Desde a Antiguidade Clássica, contudo, até o Renascimento, foi justamente o contrário que aconteceu. Em vários textos romanos descreve-se o Destino como uma mulher cega, louca e insensivel que atravessa a multidảo caminhando sobre uma pedra redonda (para simbolizar a sua instabilidade); a roda aparece com frequência nos sarcófagos, como evidente alusão ao caráter cíclico da vida. Até o final do primeiro milênio não se encontram outros exemplos valiosos sobre o tema, mas depois de alguns séculos ele ressurge com total esplendor. É na sua plenitude iconográfica que o reencontramos a partir de meados do século XIII em rosetas de várias catedrais góticas (Amiens, Trento, Lausanne) e de numerosas igrejas: pequenas figuras, representando os momentos e estados da vida, que sobem e descem pelos raios de uma roda. Um exemplo muito antigo pode ser visto no [manuscrito medieval intitulado] Hortus deliciarum, de Herrade de Landsberg, abadessa do claustro de Santa Odilia (Estrasburgo), morta em 1195. [Numa imagem deste manuscrito], como em muitas posteriores, quatro personagens que aparecem representados como reis, são movidos pela roda que é manejada pelo Destino ou Fortuna em pessoa. As legendas que acompanham os personagens nåo deixam dúvida sobre o significado da alegoria: Spes, negnabo (esperança, reinarei), diz o rei ascendente da esquerda; Gaudium, regno! (Alegria, reino!), exclama o que se encontra sobre a plataforma superior, Timor, regnavi... (Temor, reinava...) murmura o da direita, que desce de cabeça para baixo; enquanto que o quarto, que foi atirado da roda e jaz na terra, aceita a evidẻncia da sua condiçào: Dolor, sum sine regno (Dor, estou sem reino). $\hat{\mathrm{E}}$ evidente que, numa leitura alegórica, os quatro. personagens não passam de apenas um, submetido ds variações do destino. O simbolismo deste personagem quatro-em-um refere-se também às fases da lua e às idades do homem (infäncia, juventude, maturidade, velhice)". É exatamente essa alegoria que se manifesta na carta $\mathrm{X}$ de tarô que compòe, juntamente com a do coronavirus, esta nossa fotoimagem produzida com base nos recursos digitais possibilitados pelo software Movavi Photo Editor 6 for Mac - Personal.

Fontes:(https://br.pinterest.com/pin/228417012323556848/);

(http:/www .clubedotaro.com.br/site/m32_10_roda_fortuna.asp). 
NOTA 14 - A melancolia frente o conhecimento cientifico expressa na gravura de Albert Dürer, foi a inspiraç̋̊o para essa imagem. Nela, juntam-se textos que relatam tanto a importância do acaso para a ciência (www.jornaldausp/atualidades/acaso-e-importante-nas-descobertascientificas), quanto $o$ estudo de sincronicidade em situaçỏes da vida (super.abril.com.br/ciencia/acaso-marcado).

A fotografia de Einstein - feita em 1951 por um fotógrafo da agência de noticias United Press International (UPI) - está disponivel em (https://super.abril.com.br/mundo-estranho/em-que-situacao-foi-tirada-aclassica-foto-de-albert-einstein-com-a-lingua-de-fora). A partir da produçăo digital com o software Adobe Photoshop, elaboramos esta imagem que ainda contém uma representação da deusa Fortuna, acessivel: (https://produto.mercadolivre.com_br/MLB-1227681840-estatua-da-deusa-fortuna29em-china-_JM).

NOTA 15 - Esta foto-imagem foi produzida a partir de duas fotografias do acervo fotográfico de um dos autores: a da estátua do anjo e a do céu com nuvens. Uma terceira foto também participa desta foto-imagem: a do jogo senet de Amenhotep III, que teria govemado o Egito de 1390 a 1353 a.C. O senet era um jogo de mesa que provavelmente estaria baseado no suposto caminho que a alma percorreria apos a morte. $\mathbf{O}$ software de manipulaçato digital das fotografias foi Adobe Photoshop. Fonte:

(https:/les,wikipedia.org/wiki/Senet_de_Amenhotep_III)

NOTA 16 - Foto-imagem produzida com base nos recursos digitais possibilitados pelo software Movavi Photo Editor 6 for Mac - Personal, a partir de duas fotografias: 1) a da imagem $O$ ancialo dos dias de William Blake, a que já nos referimos na Nota $1 ; 2$ ) a da pintura a óleo sobre tela (1879) do pintor francês Charles Paul Landon (1760-1826) intitulada lcaro e Dédalo. Esta obra de Landon retrata o arquiteto e inventor Dédalo e seu filho Ícaro - personagens da mitologia grega - em cena, momentos antes da tragédia prevista por Dédalo e da transgressåo das leis da natureza por ĺcaro em seu desenfreado desejo tecnológico de voar com as asas dos pássaros, o que resultou em sua morte nas águas do mar Egeu.

Fontes: (https:/pt.wikipedia_org/wiki/Charles_Paul_Landon);

(https://pt. wikipedia.org/wikificaro); (https://pt, wikipedia,org/wiki/Dédalo).

NOTA 17 - Foto-imagem produzida com base nos recursos digitais do software Movavi Photo Editor 6 for Mac - Personal, a partir de uma fotografia da imagem de um afresco antigo da cidade de Pompeia que retrata pessoas jogando dados. $\mathrm{Na}$ Antiguidade, pessoas se reuniam para lançar dados sobretudo em ativididades mistico-religiosas voltadas para o propósito de se prever os destinos de pessoas que se envolviam em empreendimentos diversos que as expunham a riscos diversos ou para se prever os destinos de comandantes das cidades e dos cidadăos na tomada de decisðes politicas, econômicas, belicas etc. que envolviam o destino coletivo. Fonte da imagem; (https J/www.wikiwand.com/pt/Aleatoriedade).

NOTA 18 - Foto-imagem produzida com base nos recursos digitais do software Movavi Photo Editor 6 for Mac - Personal, a partir da foto de uma pintura do artista plástico norte-americano Paul Jackson Pollock (1912 . 1956), integrante do movimento expressionista abstrato. Desenvolvendo a técnica do dripping ou gotejamento criada pelo pintor alemåo Max Emst (1891 - 1976), Pollock respingava, ao acaso, tintas de cores diversas sobre telas colocadas no chăo, de modo que se poderia dizer que o "verdadeiro autor' de suas obras nå̀ era senåo o acaso. Os dados cúbicos brancos lançados aleatoriamente sobre a tela de Pollock saio do acervo fotográfico de um dos autores. Fontes: (https $/ / \mathrm{br}$.pinterest.com/pin/688910074220040904/); (https:/lacrilex.com.br/portfolio-item/jackson-pollock/) 
NOTA 19 - Foto-imagem produzida com base nos recursos digitais do software Movavi Photo Editor 6 for Mac - Personal, a partir de uma fotografia de uma pintura do artista plástico norte-americano Paul Jackson Pollock (1912 - 1956), integrante do movimento expressionista abstrato. Desenvolvendo a técnica do dripping ou gotejamento criada pelo pintor alemåo Max Ernst (1891 - 1976), Pollock respingava, ao acaso, tintas de cores diversas sobre telas colocadas no chão, de modo que se poderia dizer que o 'verdadeiro autor' de suas obras não era senão o acaso. Os dados cúbicos coloridos e o dado azul de 10 faces lançados aleatoriamente sobre a tela de Pollock são do acervo fotografico de um dos autores.

Fontes: (https://br.pinterest.com/pin/688910074220040904/);

(https://acrilex.com.br/portfolio-item/jackson-pollock/).

NOTA 20 - Foto-imagem produzida com base nos recursos digitais do software Movavi Photo Editor 6 for Mac - Personal, a partir de duas fotografias: 1) a da imagem $O$ anciào dos dias de William Blake, a que já nos referimos na Nota 1; 2) a de uma ilustraçào intitulada "Gota acrilica" da desenhista, ilustradora e fotógrafa russa Anna Komissarenko, explicitamente inspirada no estilo do artista plástico norte-americano Paul Jackson Pollock (1912 - 1956), integrante do movimento expressionista abstrato. Fonte da imagem: (https $J / \mathrm{pt}$,dreamstime.com/kisika-latestillustrations-vectors-clipart?pg=4).

NOTA 21 - Foto-imagem feita com base nos recursos digitais do software Movavi Photo Editor 6 for Mac - Personal, a partir de duas fotografias: 1) a de uma ilustração intitulada "Gota acrilica" da desenhista, ilustradora e fotógrafa russa Anna Komissarenko, a que fizemos referência na Nota 20; 2) a da mais precisa imagem-modelo em 3D construida do coronavirus em maio de 2020, a que fizemos referência na Nota 12.

NOTA 22 - Foto-imagem produzida com base nos recursos digitais do software Movavi Photo Editor 6 for Mac - Personal, a partir de quatro fotografias: 1) a de uma cena do famoso segmento do filme comédia satírica $O$ grande ditador (1940) de Charles Chaplin (1889 - 1977), na qual Chaplin - o diretor, produtor, roteirista, narrador e ator principal do filme -, no papel do ditador nazista Adolf Hitler, lança ao ar um globo terrestre cheio de ar e brinca com ele como se fosse uma bexiga de aniversário; 2) a da litografia intitulada Mão com esfera refletora (1935) do artista gráfico holandês Maurits Cornelis Escher (1898 - 1972); 3) a da litografia também de Escher intitulada Olho (1946); 4) a da cabeça de uma caveira com olhos vermelhos, vendida como produto para a festa de Halloween no site da loja portuguesa Misterius. Fontes:

(https:/www.dw.com/pt-br/charlie-chaplin-adolf-hitler-e-o-cinema/a-

18921641);

(https://mcescher.com/gallery/italian-

period/\#iLightbox[gallery_image_1 $1 / 148$ );

(https://mescher,com/gallery/back-in-

holland/HiLightbox[gallery_image_I]/21);

(https://www.misterius.pt/pt-pt/produto/cabeca-caveira-esferovite). 
NOTA 23 - A situaçào de desgoverno pela qual passa o Brasil foi a inspiração para esta foto-imagem. Nela, encontram-se a capa do livro Leviatã, de Thomas Hobbes (1588-1679) - cujo livro completo está disponivel na Herzog August Bibliothek, acessivel num dos links abaixo referidos -, fotografias de queimadas na Amazônia e túmulos abertos para enterro de vítimas de Covid 19. Compõem também esta foto-imagem, partes de dois textos: um sobre a politica externa do governo Bolsonaro e outro que analisa o modus operandi de governos golpistas. A manipulação digital se deu com Adobe Photoshop.

Fontes:(http//www.hab.de/en/home html);(https://forskning.no/klima-kommentar/det-erikke-klimaet-du-trenger-a-bekymre-deg-for-nar-regnskogen-brenner-det-er-det-

biologiske-mangfoldet/1551263);(https://portalvarada.com/ultimas-noticias/coronavirusnumero-de-mortes-no-brasil-esta-acima-do-

esperado);(https//entendendobolsonaro,blogosfera.uol.com.br/2020/01/15/trump-oudeus-bolsonaro-conta-com-acaso-na-politica-externa/);

(https:/www.cartamaior.com,be//Editoria/Politica/Na-nossa-America-nao-existecoincidencia-nem-acaso-na-politica-14/32985)

NOTA 24 - Foto-imagem produzida com base nos recursos digitais possibilitados pelo software Movavi Photo Editor 6 for Mac - Personal, a partir de duas fotografias: 1) a da ilustração intitulada "Deméter/Ceres" - respectivamente deusas grega e romana da agricultura, da terra cultivada - do desenhista gráfico e ilustrador espanhol Arturo Ruiz; 2) a da fotografia Nuvens pertencente ao arquivo pessoal de fotos de um dos autores.

Fontes: (https://www behance net/portafolioarturoruiz):

(https://br.pinterest.com/bandolero44/mitologia-griega-y-

romana/);(https//br.pinterest.com/pin/760334349559426573/).

NOTA 25 - Foto-imagem produzida com base nos recursos digitais do software Movavi Photo Editor 6 for Mac - Personal, a partir de duas fotografias: 1) a da pintura a óleo intitulada $A$ alegoria da Fortuna (1615-1620) do pintor belga Frans Francken o Jovem (1581-1642);2) a da pintura a óleo de 1818 intitulada $A$ balsa de Medusa ( Le Radeau de la Méduse) do pintor e litografo francés Théodore Géricault (1791-1824), que foi produzida a partir do impacto nele gerado pelo naufrágio da Fragata de Medusa que havia partido da França rumo a Senegal, na Africa, no ano de 1816, e a cena retrata os tripulantes desesperados lutando à deriva logo após o inicio do naufrágio. A técnica por nós utilizada para a produção desta foto-imagem foi a da colagem composicional por sobreposição das foto-imagens das duas pinturas acompanhada de um ajuste aleatório da opacidade da segunda foto-imagem sobre a primeira, até se atingir o efeito performativo desejado. Fontes:

(https:/www.louvre. fr/en/oeuvre-notices/allegory-fortune);

(htips:/pt.wahooart.com/@@/ARAAQN-Francken-Frans-li-(Francken-Le-Jeune)ALEGORIA-DA-ACASO); (https://pt.wikipedia.org/wiki/A_Balsa_da_Medusa).

NOTA 26 - Foto-imagem produzida com base nos recursos digitais do software Movavi Photo Editor 6 for Mac - Personal, a partir de duas fotografias: 1) a da pintura a óleo intitulada Fortuna com os olhos vendados (1754) do pintor polonês Tadeusz Kuntze (1733 - 1793); 2) a da pintura a óleo de 1818 intitulada $A$ balsa de Medusa ( Le Radeau de la Méduse) do pintor e litógrafo francês Théodore Géricault (1791-1824), a que nos referimos na Nota 25. A téenica por nós utilizada para a produção desta nossa foto-imagem foi a da colagem composicional por sobreposiçầo das foto-imagens das duas pinturas acompanhada de um ajuste aleatório da opacidade da segunda foto-imagem sobre a primeira, até se atingir o efeito performativo desejado.

Fontes: (https://en.wikipedia.org/wiki/Tadeusz_Kuntze)?

(https:/pt.wikipedia.org/wiki/Fortuna_(mitologia)tt/media/Ficheiro:KuntzeKonicz_Fortune.jpg). 
NOTA 27 - Foto-imagem produzida com base nos recursos digitais do software Movavi Photo Editor 6 for Mac - Personal, a partir de duas fotografias: 1) a da pintura a óleo intitulada Fortuna com os olhos vendados (1754) do pintor polonés Tadeusz Kuntze (1733 - 1793), a que fizemos referência na Nota $26 ; 2$ ) a de um busto de medusa com olhos vendados com uma tarja vermelha, acessivel no site:

(https://br.pinterest.com/pin/639581584570091657D.

NOTA 28 - Foto-imagem produrida com base nos recursos digitais do software Movavi Photo Editor 6 for Mac - Personal, a partir de duas fotografias: 1) a do Arcano IX do baralho de Taró do artista chileno contemporâneo Ignacio Cobo, cujas cartas foram produzidas através de colagens digitais de outras obras artisticas que transfiguram os arcanos maiores e menores tradicionais com base em associaçôes artistico-criativas livres e casuais. Conforme esclarece Cobo em sua página do Instagram, o Arcano IX do seu baralho de tarô é o halloween da capa do "Witches Cauldron Volume II" editado pelos talentosos de @soulfulxnature, cujas ilustraçòes artisticas foram produzidas por ele próprio. Tal obra pode ser baixada gratuitamente no endereço:

(http://soulfulxnature.com/witches-cauldron-ii); 2) a de uma das fotografias do conjunto intitulado Controlled Burns do multiartista norte-americano Kevin Cooley. O conjunto de fotografias de nuvens de fumaças de Cooley é produzido a partir de fogo real, mas com o propósito de se produzir efeitos estéticos performativos. E como o próprio nome da série indica, embora as nuvens de fumaça produzidas pelo fogo real adquiram formas casuais inusitadas e imprevistas, o fotógrafo não só tenta exercer um certo controle sobre o tipo de fumaça, forma, cor, densidade e textura que deseja produzir, com base na escolha prévia do material a ser incinerado, como também escolhe os momentos estéticos performativos a serem registrados por sua câmera fotográfica. Como ele próprio destaca em sua biografia artistica, Cooley "trabalha com as forças elementares da natureza para questionar os sistemas de conhecimento que se relacionam com nossas percepçôes e experiências da vida cotidiana. Usando fotografia, video e instalaçăo, ele cria estruturas através das quais observar gestos experimentais e performativos para decifrar nossas relaçỏes complexas e em evolução com a natureza, a tecnologia e, finalmente, uns com os outros". A técnica por nós utilizada para a produção desta nossa foto-imagem foi a da colagem composicional por sobreposição das duas foto-imagens acompanhada de um ajuste aleatório da opacidade da segunda foto-imagem sobre a primeira, até se atingir o efeito performativo desejado. Fontes

(http://www.kevincooley.net/info);(https://or.pinterest.com/pin/710654016174321494/):

(https://ignaciocobotarot.tumblr.com/post/124508849101/digital-collage-by-ignacio-cobomore-art-on-tumblr); (https://www.instagram.com/ignacio.cobo/);

(https://rickwayne.blog/2018/10/13/ignacio-cobos-tarot/);

(http://www ideafixa com/oldbutgold/fumaca-e-fogo);

(http://www.kevincooley.net/y304er70jwfaop8fla2iruogrfy $5 \mathrm{~g}$ ).

NOTA 29 - Foto-imagem produzida com base nos recursos digitais do software Movavi Photo Editor 6 for Mac - Personal, a partir de: 1) uma foto do filósofo austriaco Ludwig Wittgenstein (1889-1951); 2) uma foto recente de Arlete Brito, autora deste álbum; 3) uma foto recente de Antonio Miguel, usando óculos, também autor deste álbum. A foto que elegemos do filosofo para produzir a nossa foto-imagem \& a mesma eleita por Michael Nedo para compor a capa de seu livro intitulado Wittgenstein and Cambridge Family Resemblances (NEDO, 2011), o qual pode ser livremente baixado no site abaixo referido. $\mathrm{O}$ aforismo "Uma fotografia compósita é uma probabilidade, nåo um acaso" por nós produzido para caracterizar esta nossa fotoimagem é uma paráfrase do aforismo de Wittgenstein "Uma fotografia galtoniana é a imagem de uma probabilidade" que aparece no segmento 235 das Obsenvaçōes filosóficas (WITTGENSTEIN, 2005, OF-235, p. 241). Com base nesse aforismo, é provável que a foto-imagem do rosto previsivel de ninguém que produzimos se assemelhe à face invisivel do acaso, assim como a sobreposição de fotos da Terra, do Sol e da Lua provavelmente se assemelhe com a face oculta da Lua. 
Por sua vez, a fim de caracterizar o tipo de interesse que Wittgenstein demonstrou pelas fotografias compósitas do antropólogo, meteorologista, matemático e estatistico inglés Francis Galton (1822 - 1911), julgamos pertinente transcrever na integra a esclarecedora nota 160 à qual João J. R.L. Almeida remete o leitor da sua tradução das Investigações filosóficas (WITTGENSTEIN, s/d), para esclarecer o seguinte aforismo (IF-568) do filósofo: "Se compreendo corretamente o caráter do jogo-poderia dizer , entâo isso não pertence essencialmente a ele. ( $O$ significado, uma fisiognomia)": "Mantive a palavra fisiognomia na mesma formulação de uma antiga forma de estudo que tentava desvendar o caráter de uma pessoa pelas suas expressర̃es faciais, [posto que ela] remete a uma inter-relação, presente ao longo de toda a obra de Wittgenstein, entre significação, visão de aspecto, físiognomia e expressão. A primeira vez que Wittgenstein utiliza o termo [...] ele o correlaciona à visão do mundo sub specie aeternitatis com a vontade ou espirito (Geist) que pode ser inferido no que se mostra de uma expressão. Trata-se, aparentemente, neste caso, de inferências de tipo transcendental que ocorrem de forma independente do mundo empirico, quando este está, porém, internamente sistematizado numa totalidade significativa. No contexto da disputa entre inefabilistas e resolutistas, no que tange à validade da doutrina do dizer/mostrar no Tractatus, a solução desse problema deveria passar, a meu ver, pela discussão da naturalidade dessa variaçẫo, tanto na linguagem ordinária quanto no caráter literário, e não somente filosófico, de um texto como o Tractatus. Uma fisiognomia pode ser concebida precisamente como uma marca em que esse tipo de ambiguidade estética ế uma possibilidade perceptiva. Jả [...] por volta de 1946, vemos, no uso de uma palavra, também uma fisiognomia, [...] o que testemunha a ideia da fisiognomia orientando as noçōes de limite, de variabilidade e de multiplicidade, quando todo esse jogo de linguagem estă relacionado ả compreensão de fenômenos tăo simples como um sorriso. E até mesmo nas atividades recreacionais, Wittgenstein, interessado no aspecto gramatical dos experimentos fisiognômicos de Galton, monta sua própria semelhança de familia na seguinte foto (NEDO, 2011, p. 32) que ele criou, na década de 1920, com a ajuda do fotógrafo Moritz Năhr, juntando a sua própria fotografia com as das suas trếs irmås (Gretl, Helene e Hermine), e formando com elas um só compósito.

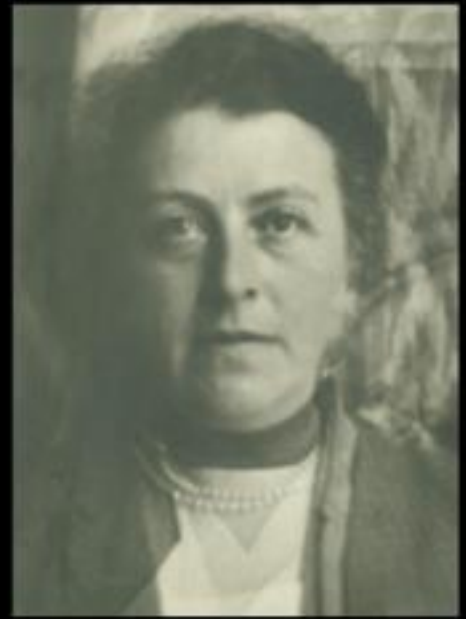

Existe a possibilidade de que Wittgenstein estivesse se referindo a esta foto [...] quando pretendia dizer que a ética era uma "pergunta sobre o significado da vida", sobre o que "faz a vida valer a pena ser vivida", ou sobre "a maneira correta de viver"; "Bem, agora vou usar o termo Ética num sentido ligeiramente mais amplo. Num sentido que, de fato, inclui o que acredito ser a parte mais essencial do que ê geralmente chamado de Estética. 
E para que vocếs vejam bem claramente o que presumo ser a questăo central da Ética, colocarei diante de vocês um certo número de expressōes mais ou menos sinônimas, em que cada uma delas poderia ser substituida pela definiçầo acima, e, ao enumerá-las, quero produzir o mesmo tipo de efeito que Galton produziu quando pegou um certo número de fotografias de diferentes rostos $\mathrm{e}$ colocou na mesma placa fotográfica para obter a imagem dos traços tipicos que todos eles tinham em comum. E, ao mostrar para vocếs uma foto coletiva como essa, eu poderia fazê-los ver o que é um - digamos - tipico rosto chinès; assim, se vocés olharem para a extensão da série de sinônimos que colocarei diante de vocés, serăo, assim espero, capazes de ver os traços caracteristicos que todos têm em comum, e esses são os traços característicos da Ética". Desse modo, o que temos aqui é uma criaçào descritiva, uma invençåo empirica, uma construçào de um fato, ou de um mundo, digamos assim, nào destituida de certos interesses ou objetivos metodológicos, tal como um ver como ou um ver um aspecto" (ALMEIDA, in WITTGENSTEIN, s/d, Nota 160, p. 386-387). Fontes das imagens e informaçōes:

NEDO, Michael. Wittgenstein and Cambridge Family Resemblances. Supported by the Austrian Cultural Forum, London. Typset in Baskerville and Gil Sans by Berthold, 2011.

(https://www.academia,edu/4670400/Wittgenstein_and_Cambridge_Family_R esemblances_A_presentation_by_Michael_Nedo).

WITTGENSTEIN, L. Obsenvaçס̃es filosóficas. São Paulo: Ediçð̄es Loyola, 2005.

WITTGENSTEIN, L. (s/d) Investigações filosóficas/Philosophische untersuchungen. Edição bilingue alemão/português. (J. J. R. L. de Almeida, Ap. Trad. e Notas). Wittgenstein Translations.

(http://www.psicanaliseefilosofia,com.br/textos/).

NOTA 30 - Foto-imagem produzida com base nos recursos digitais do software Movavi Photo Editor 6 for Mac - Personal, a partir de três fotografias: 1) uma das serigrafias compósitas (1994) - acessiveis em (NEDO. 2011, p. 34-36) - que o artista plástico e escultor escocês Eduardo Luigi Paolozzi (1924-2005) fez do filósofo austriaco Ludwig Wittgenstein (18891951), compondo o rosto do filosofo com o do músico e compositor inglês John Lennon e com imagens gregas e astecas esculpidas em pedra; 2) uma foto recente de Arlete Brito, autora deste álbum; 3) uma foto recente de Antonio Miguel, usando óculos, também autor deste álbum. Sobre fotografias compósitas, ver Nota 29. Fonte da imagem:

NEDO, Michacl. Wittgenstein and Cambridge Family Resemblances. Supported by the Austrian Cultural Forum, London. Typset in Baskerville and Gil Sans by Berthold, 2011.

(https://www.academia.edu/4670400/Wittgenstein_and_Cambridge_Family_R esemblances_A_presentation_by_Michael_Nedo). 
NOTA 31 - Foto-imagem produzida com base nos recursos digitais do software Movavi Photo Editor 6 for Mac - Personal, a partir de três fotografias: 1) a de uma réplica em cristal da escultura Victória de Samotrácia (1962) - a Vênus azul alada do artista plástico francés Yves Klein (1928 - 1962) - produzida por artesåos do museu Lalique - criado pelo joalheiro francếs de vanguarda, René Jules Lalique (1860 - 1945) - e que foi exposta nesse museu de 27 de abril a 4 de novembro de 2018, foto-imagem esta acessivel no primeiro dos sites abaixo referidos; 2) a de uma outra foto-imagem da mesma Vênus de Klein, acessivel no segundo dos sites abaixo referidos; 3) a de uma escultura em mármore - esculpida por um artista romano anônimo, no século I d. C. - de Livia Drusila ou Julia Augusta (59/58 a.C 29 d.C.) - a terceira esposa do imperador romano Augusto ( 63 a.C. - 14 d.C.) retratada como $O p s$, a deusa grega da abundaincia e da fertilidade, segurando um ramo de trigo em uma das måos e uma cornucópia na outra, acessivel no terceiro dos sites abaixo referidos. Já o que estamos denominando místico international blue de Klein - isto é, o International Klein Blue (IKB) ou simplesmente Azul de Klein é o nome que passou a ser atribuido ao tom de azul que Klein imprimia às suas pinturas e esculturas monocromáticas, obtido através de uma determinada mistura de pigmentos que foi registrada em 19 de maio de 1960 no Instituto Nacional da Propriedade Industrial, sob o número 63471. Fontes das foto-imagens:

(http://www.yvesklein.com/fr/expositions/view/1562/prisme-quand-le-cristal-

lalique-rencontre-1-art-contemporain/?of $=31$ ):

(http//www_yvesklein.de/yves_klein.html);

(https:/vignette.wikia nocookie.net/olympians/images/Z//8/Fortuna-

Prosper.JPG/revision/latest?cb=20120305054729);

(https://pt.wikipedia.org/wiki/International_Klein_Blue).

NOTA 32 - Foto-imagem produzida com base nos recursos digitais do software Movavi Photo Editor 6 for Mac - Personal, a partir de uma fotografia de uma pena flutuando em um fundo preto, acessivel no site: (https:/br.pinterest.com/pin/855191416730743106/).

NOTA 33 - Foto-imagem produzida com base nos recursos digitais do software Movavi Photo Editor 6 for Mac - Personal, a partir de uma fotografia de bolhas de sabł̊o produzida pelo fotógrafo @holiday.photo.top para a freepikcompany. Fonte: (https:/br.freepik.com/fotos-premium/bolhas-de-sabao-isoladas-em-um-fundopreto_8439550,htm). 